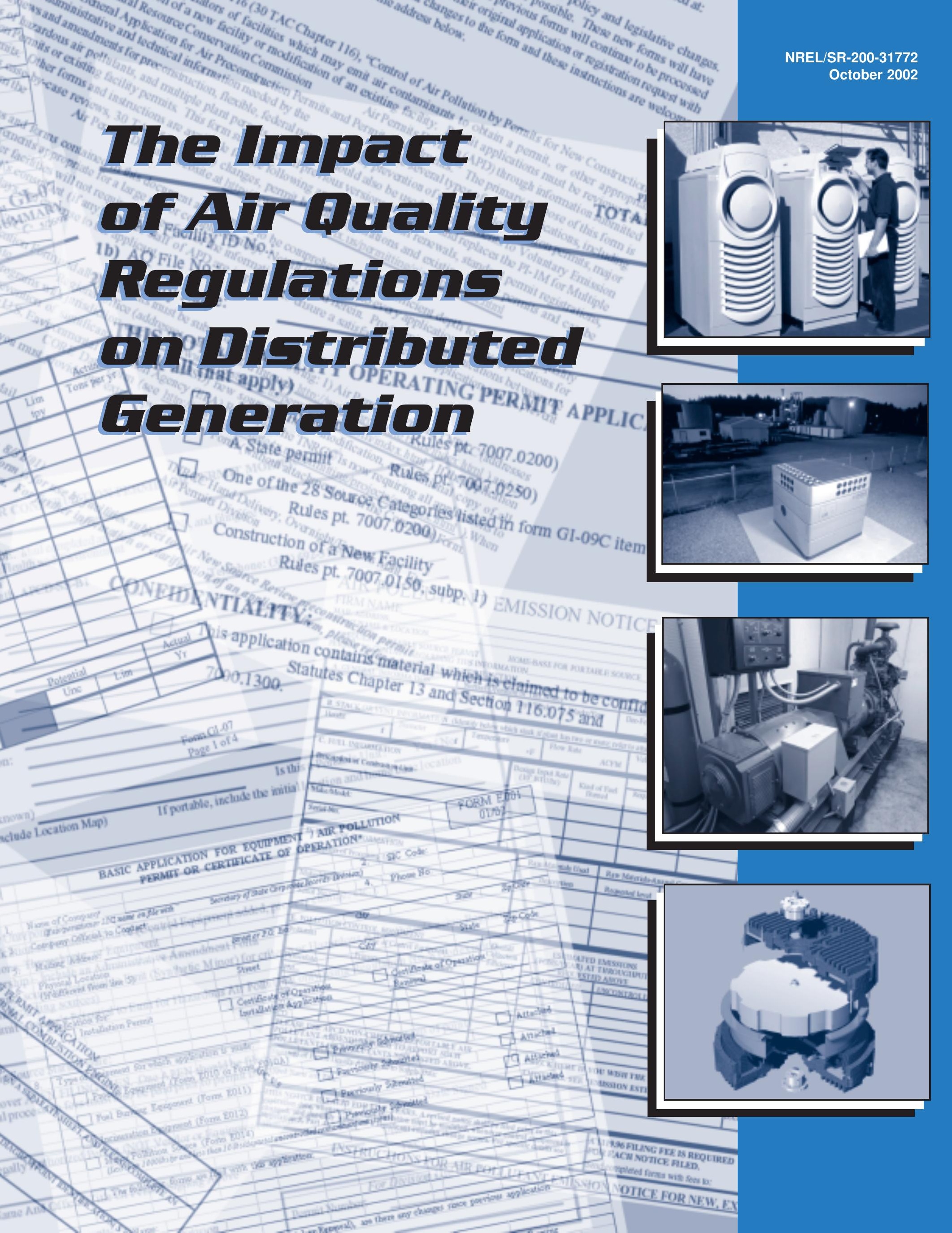


October 2002 • NREL/SR-560-31772

\section{The Impact of Air Quality Regulations on Distributed Generation}

\section{April 2002-10 May 2002}

Joel Bluestein

Energy and Environmental Analysis, Inc.

Arlington, Virginia

Susan Horgan

Distributed Utility Associates

Livermore, California

M. Monika Eldridge

Competitive Utility Strategies

Boulder, Colorado

NREL Technical Monitor: Gary Nakarado

Prepared under Subcontract No. ACM-2-32039-01

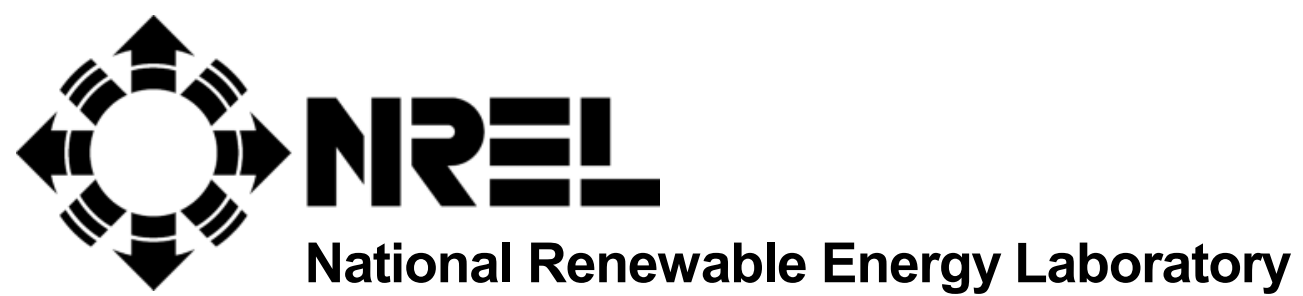

1617 Cole Boulevard

Golden, Colorado 80401-3393

NREL is a U.S. Department of Energy Laboratory

Operated by Midwest Research Institute $\bullet$ Battelle $\bullet$ Bechtel

Contract No. DE-AC36-99-G010337 


\section{NOTICE}

This report was prepared as an account of work sponsored by an agency of the United States government. Neither the United States government nor any agency thereof, nor any of their employees, makes any warranty, express or implied, or assumes any legal liability or responsibility for the accuracy, completeness, or usefulness of any information, apparatus, product, or process disclosed, or represents that its use would not infringe privately owned rights. Reference herein to any specific commercial product, process, or service by trade name, trademark, manufacturer, or otherwise does not necessarily constitute or imply its endorsement, recommendation, or favoring by the United States government or any agency thereof. The views and opinions of authors expressed herein do not necessarily state or reflect those of the United States government or any agency thereof.

Available electronically at http://www.osti.gov/bridge

Available for a processing fee to U.S. Department of Energy and its contractors, in paper, from:

U.S. Department of Energy

Office of Scientific and Technical Information

P.O. Box 62

Oak Ridge, TN 37831-0062

phone: 865.576 .8401

fax: 865.576.5728

email: mailto:reports@adonis.osti.gov

Available for sale to the public, in paper, from:

U.S. Department of Commerce

National Technical Information Service

5285 Port Royal Road

Springfield, VA 22161

phone: 800.553 .6847

fax: 703.605 .6900

email: mailto:orders@ntis.fedworld.gov

online ordering: http://www.ntis.gov/ordering.htm

Printed on paper containing at least $50 \%$ wastepaper, including $20 \%$ postconsumer waste 


\section{United States Department of Energy Office of Energy Efficiency and Renewable Energy Office of Distributed Energy and Electricity Reliability}

Joseph Galdo

Manager, Distribution and

Interconnection R\&D

EE-2D/Forrestal Building

U.S. Department of Energy

1000 Independence Avenue SW

Washington, DC 20585

Phone: (202) 586-0518

Fax: (202) 586-1640

E-mail: joseph.galdo@,hq.doe.gov

\author{
$\underline{\text { Richard DeBlasio }}$ \\ NREL Distributed Energy Resources \\ Technology Manager \\ National Renewable Energy Laboratory \\ 1617 Cole Blvd. (MS 3214) \\ Golden, CO 80601 \\ Phone: (303) 275-4333 \\ E-mail: dick_deblasio@nrel.gov
}

\author{
Gary Nakarado* \\ NREL Distributed Energy Resources \\ Policy Lead \\ National Renewable Energy Laboratory \\ 1617 Cole Blvd. (MS 3214) \\ Golden, CO 80601 \\ Phone: (303) 275-3719 \\ E-mail: gary nakarado@nrel.gov
}

*Contact for questions or comments on this report.

\section{ABOUT THE AUTHORS}

\section{Joel Bluestein}

Joel Bluestein, president of Energy and Environmental Analysis, Inc. (EEA), is a nationally recognized expert on the market impacts of environmental regulation. Mr. Bluestein has been tracking and analyzing the development and market impacts of the Clean Air Act Amendments of 1990 since their inception, in particular as they affect the power generation and industrial sectors. He is an expert on emission trading programs and has been directly involved in the development of programs including the Ozone Transport Region $\mathrm{NO}_{\mathrm{x}}$ Budget program, the Open Market Trading Rule, OTAG recommendations on emissions trading, the State Implementation Plan (SIP) call $\mathrm{NO}_{\mathrm{x}}$ cap and trade program, and issues related to carbon trading. He holds a degree in mechanical engineering from MIT and is a registered professional engineer.

\section{Susan Horgan}

Susan Horgan is a founding associate with Distributed Utility Associates (DUA). Her efforts focus on managing a wide range of research projects that assess the impact of deploying the distributed utility concept, including a number of projects that estimate the market potential of distributed generation for various technologies and applications, and the distributed utility integration test, an effort to assess the electrical impact of distributed generation and storage devices on the electric distribution system. Prior to coming to DUA she worked in research and development for Pacific Gas and Electric Co. She has a BA in economics and political science from San Jose State University.

\section{Monika Eldridge}

Ms. Eldridge was a principal with Competitive Utility Strategies, LLC where until her death in a Yosemite climbing accident she was the principal investigator on this project. She was co-author of the report, Making Connections, which investigated the barriers to the interconnection of distributed generation to the utility distribution system. Ms. Eldridge developed distributed generation and renewable energy projects and evaluated the economics and technical feasibility of such projects. During her 18-year career in the power generation industry, she assisted utilities in strategic planning of major power plant facilities and worked as a project manager for CMS Energy. She had a BS in mechanical and aerospace engineering from the University of Delaware and was a registered professional engineer.

Cover Photos (top to bottom):

The Capstone microturbine is an example of small modular equipment now available for distributed electrical generation. Courtesy of Capstone Turbine Corporation. NREL PIX \#08130

This hydrogen-powered fuel cell from Ballard Power Systems is an example of new ultra-low-emission equipment available for distributed electrical generation. Courtesy of Ballard Power Systems. NREL PIX \#02005

Renewable energy technologies such as wind and solar power will often be paired with fossil energy technologies such as this diesel generator for continuous distributed generation capability. Photo by Warren Gretz. NREL PIX \#02138

Energy storage also serves distributed generation needs such as power reliability. This flywheel is an example of innovative new storage technologies well suited to distributed use. Courtesy of Active Power, Inc. NREL PIX \#11567 


\section{Foreword}

Air quality permitting has been claimed to be a major impediment to deploying fossil-fueled distributed energy technologies, second in impact only to the process of interconnecting with the grid. In examining this claim, the authors of this report note that air quality permitting issues are primarily related to minor source review in nonattainment areas. At first, this may appear to be a limited problem with not much impact on the market for distributed generation. Upon reflection, however, it is clear that the nonattainment areas are where the population centers are located; where industrial and commercial electric loads are concentrated; where the transmission and distribution systems are most likely to be aged and under stress and to have capacity constraints; where reliability is an issue; and where distributed generation is most needed. Nonattainment areas are also the areas of the nation where combined heat and power and clean distributed generation can be of most benefit to the environment.

Distributed energy resources have a major role in shaping our nation's electricity energy future. The authors' recommendations and conclusions challenge us to improve our air quality regulation process to accommodate this role while meeting the nation's air quality goals. I believe that this is not only necessary, but is also possible to accomplish. A new framework for the regulation of emissions from distributed energy projects is being developed by a collaborative of utility and air regulators, environmentalists and distributed energy industry representatives. If embraced by state air regulators, this framework could provide a basis for regulating air emissions from small distributed-generation projects based on reasonable emissions limits and a streamlined process for the environmental permitting of pre-certified equipment. Providing credit for combined heat and power, for the use of waste fuel and for efficiency measures, it could be a major step in reconciling the issues with the current permitting process identified in this report.

This report underscores that fact that the air quality permitting process can discourage distributed energy projects that would provide a net benefit to the environment. As in the case for traditional utility regulation, environmental regulation was not designed with distributed generation in mind. State and federal regulators have begun to address the utility regulation issues related to distributedenergy technologies, particularly those dealing with interconnection with the grid. Hopefully, this report will stimulate both state and federal action to reformulate air quality regulation to address the unique characteristics of distributed-energy projects as well.

Joseph F. Galdo

Manager, Distribution and Interconnection R\&D

Distributed Energy Resources and Electric Reliability

Office of Technology Development

Energy Efficiency and Renewable Energy

U.S. Department of Energy 


\section{Executive Summary}

Relatively small projects for generating electrical power at or near the point of use - distributed generation (DG)—offer unique opportunities for enhancing the U.S. electric system. This report finds that current air quality regulatory practices are inappropriately inhibiting the development of DG through a failure to recognize the environmental benefits offered by DG or by imposing requirements designed for larger systems that are not appropriate to DG systems. The report recommends that air quality regulation be made more efficient and appropriate for DG by establishing national standards for DG equipment. This report also recommends that DG projects be evaluated on a "net" emissions basis by being given credit for any emission sources that they displace. Air quality regulation should also recognize and account for the benefits of combined heat and power (CHP).

New technologies and applications, along with recent energy marketplace disruptions such as rolling blackouts and price surges, are spurring great interest in DG. These new and established DG technologies_-such as small gas turbines and reciprocating engines, microturbines, fuel cells, and renewable technologies - are best suited for mass production as standardized, off-the-shelf products. Several of the new DG applications — such as heating and air conditioning systems run from the otherwise wasted heat of electricity generators (CHP) and the conversion to electricity of waste and by-product fuels that are otherwise flared or released—such as oil-field natural gas or landfill-generated methane - are inherently efficient and environmentally beneficial. Others - such as guaranteeing high-quality power for sensitive operations, emergency backup, and peak shaving - are difficult or impossible to serve from central generating facilities. Would-be installers of DG facilities, however, are finding a variety of barriers to what they expect should be seen as publicly beneficial projects. Not the least of these is obtaining emission permits from air quality agencies.

With a few emerging exceptions, air quality programs do not properly recognize the environmental benefits of DG or the ways in which DG is different from the larger projects for which the programs were developed. This report analyzes air quality programs as they apply to DG, provides examples of their impact on specific projects, and concludes that certain air quality permit and equipmentspecific regulations are inappropriately hindering the development of DG.

DG technology should be recognized as being most cost effective and potentially environmentally beneficial when standardized and sold-off-the shelf. Case-by-case regulation and costly add-on pollution control equipment are burdensome for both developer and regulator and inhibit the development of the DG equipment manufacturing industry. More importantly, they are not consistent with the basic principles or goals of air quality regulation. Therefore, consistent national air emission standards should be established for DG equipment and air quality programs should be encouraged or required to accept equipment that is certified as meeting those standards.

DG technology is well suited to using what would otherwise be wasted fuel such as flared 
natural gas from oil fields or methane from landfills. The emission levels attributed to these DG projects should not include the emissions that were being generated by flaring. DG CHP projects should also be recognized for reducing use of other thermal process equipment and associated air emissions. Similarly, if a CHP project replaces old thermal equipment or a $\mathrm{DG}$ project replaces an existing emergency generator, the emission levels attributed to the new equipment should be reduced by the levels that the old equipment was generating. Air quality regulation of new DG should therefore take into account the avoided emissions of displaced power generation and thermal processing. Federal regulation of major new sources (not typically applicable to DG) does include "netting" provisions that largely address this problem. Air quality regulations should be amended to apply netting to state regulation of minor sources as well.

DG projects — and regional air quality_would also benefit from implementing an emissions trading system for small generators. Such systems have been shown to be a cost-effective, flexible regulatory approach to reducing emissions and encouraging the use of clean technologies such as DG.

This report therefore recommends that appropriate agencies and policymakers take the following actions with respect to air emissions permitting for DG projects:

- Develop uniform, achievable national air emission standards for DG.

- Provide credit for CHP in air quality permitting.

- Provide credit for avoided or offset emissions in air quality permitting.

- Apply market-based regulatory structures such as emission trading programs in a manner that will allow DG participation.

Scope-This report illustrates the effect of air quality permitting by examining a variety of recent DG projects and identifies a number of ways in which the present regulatory structure and application of air quality regulations are inefficient or inappropriate in their treatment of DG. The report analyzes these issues and presents recommendations for developing integrated national and state policies that would promote clean DG in ways consistent with national and state air quality goals.

DG is generally defined as electricity generation located at or close to the point of use. ${ }^{1}$ This study focuses on small-less than 15 megawatts (MW) per unit—fossil-fueled distributed electric generators and in particular on:

- Gas-fired technologies

- CHP applications

- Technologies with inherently low emissions

- Applications that use waste or byproduct fuels

Study Design - This study reviewed the current framework of air emission permitting applicable to DG and analyzed specific DG project case studies to determine the effect of emission permitting on the development and deployment of DG. More than 200 industry experts, air regulators, U.S. Department of Energy (DOE), and U.S. Environmental Protection Agency (EPA) staff, and DG project developers were contacted and 51 potential case studies were identified. Telephone interview investigations of the 51 cases were used to identify key obstacles to DG deployment, which then became the focus for developing recommendations. Selected cases were then chosen to illustrate the most

\footnotetext{
${ }^{1}$ The definition of DG is discussed further in Chapter 2.
} 
significant permitting issues in this report. For those cases, additional follow-up was done to verify key facts. This study is not a statistical survey of DG projects. Rather, it seeks to identify structural issues in the air quality regulation of DG that could be changed to promote environmentally beneficial DG technologies and applications.

Role of $\boldsymbol{D G}$-There is a variety of drivers for the increased interest and development of DG. Most notably, small on-site electric generators can better serve certain needs than central generation can. For example:

- Emergency generation

- Peak shaving

- Power quality and reliability

- $\mathrm{CHP}$

New interest in DG has also been spurred by improvements in existing technology and the development of new technologies for very small, on-site generation. Microturbines, fuel cells, and improved combustion turbines and reciprocating engines allow flexible, efficient, clean, and low-cost DG. These technologies are the primary focus of this study. A critical factor is that these small system technologies are intended to be mass-produced and installed in a standardized fashion. They can be designed to limit emissions through the use of clean fuels and inherently low-emitting combustion technology, but are not suitable for the use of "add-on" emission controls such as those used for large electricity generators. Such add-ons are typically very expensive for these small systems on a per unit basis and often are too complex, or use noxious reagents inappropriate for the small commercial and other markets targeted by DG developers.
Air Emission Permitting-The Federal Clean Air Act requires pre-construction environmental permitting of new stationary facilities in order to meet the goals of the National Ambient Air Quality Standards (NAAQS) program. The "criteria pollutants" regulated under this program that are of greatest relevance to DG are nitrogen oxides $\left(\mathrm{NO}_{\mathrm{x}}\right.$ ) (as a precursor to ground level ozone or smog), carbon monoxide (CO), sulfur dioxide $\left(\mathrm{SO}_{2}\right)$, and particulate matter $(\mathrm{PM})$. $\mathrm{NO}_{\mathrm{x}}$ is the primary (and often the only) criteria pollutant that significantly affects most DG projects. The most significant impact on DG generally comes from state minor source review in nonattainment areas.

While nonattainment areas now constitute a small geographic fraction of the United States, they include the large urban areas, which are major markets for DG. Moreover, it is anticipated that the areas of nonattainment will expand over the coming years and bring more stringent air standards. Also, as DG use expands, more attention will be paid to its emission impacts, particularly from a regional perspective.

Although the permitting process is established and regulated under federal law, it is administered by the states. This leads to a high degree of variability in implementation, ranging from no control requirements to extremely stringent levels of control.

The recommendations of this report seek to ameliorate the often inappropriately burdensome impact of these regulatory variations on DG without sacrificing air quality protection.

For additional information on distributed generation, please see the U.S. Department of Energy's Distributed Energy Resources Web site http://www.eren.doe.gov/distributedpower/. As indicated in this report, air quality regulations and their impact vary greatly from state to state. We expect soon to add to the Web site a "Regulatory Requirements Database for Small Electric Generators" containing considerable state-specific information plus general information on regulatory impacts. 


\section{Key Findings and Recommendations}

\section{Emissions Credit for CHP}

- Finding: Making use of the one-half to two-thirds of energy lost as waste heat in most electrical generation is the easiest and best way to increase the overall efficiency of the nation's thermal and electric generation infrastructure. Because DG occurs near the user, it provides far more opportunities to use this waste heat in CHP applications than do large central generation plants. Very few air emission programs, however, currently give direct credit for the thermal application side of CHP projects. None of the $14 \mathrm{CHP}$ case studies evaluated for this report received credit for applying CHP.

- Recommendation: Air quality permitting should provide credit for both the thermal and electric output of CHP projects. This can be done either as a netting reduction or as part of calculating compliance with fixed emission limits.

\section{Emissions Credit for Avoided or Displaced Emissions}

- Finding: DG projects are uniquely suitable for using otherwise wasted fuel such as flared natural gas or methane from landfills. CHP DG projects may replace thermal equipment such as boilers. In most of these cases DG projects are not credited for the avoided or displaced emissions. This discourages replacement of old high-emission equipment and beneficial use of wasted energy.

- Recommendation: Air quality permitting should provide credit for avoided or displaced emissions when DG projects replace existing equipment or use fuels or wastes previously flared or incinerated. As with CHP, this can be done by netting or with credits in calculating emission compliance levels.

\section{Uniform Standards for DG Equipment}

- Finding: The complex, case-by-case permitting process designed for "large" generators is inherently incongruous with application to small, standardized DG technologies relying on "mass production" and ease of installation for their economic viability.

- Finding: The cost of add-on air emission control technologies is relatively insensitive to size. Applying stringent add-on or percentage reduction requirements to small projects such as DG typically costs far more per unit of electricity produced or pollutant emitted than for large projects, especially if the small projects are inherently clean to begin with.

- Finding: Current emission permit systems based on requiring add-on pollution control equipment and caseby-case review processes give little or no credit for the initial choice of inherently low-emission generating equipment or the development of built-in pollution prevention technology that reduces emissions more effectively than add-on equipment.

- Recommendation: Air quality permitting for DG should be based on uniform national standards for DG equipment. Those standards should be output-based; i.e. maximum units of emissions per unit of energy produced. The standards should be reasonably achievable and should allow equipment to be pre-certified as meeting regulatory standards. This would also recognize and encourage inherently low-emission and higher efficiency equipment design.

\section{Market-Based Regulatory Structures}

- Finding: Experience has shown that emission trading in the United States is a cost-effective and flexible structure for emission reduction. Administration proposals for future environmental regulation are expected to rely heavily on such mechanisms.

- Recommendation: Market-based air quality regulatory programs such as emissions trading should specifically provide for participation of DG projects.

\section{Outreach and Education}

- Finding: Most air regulatory programs are administered by state regulators who have limited knowledge of DG technologies or applications. Many DG developers have little knowledge of the regulatory programs.

- Recommendation: Provide outreach and training on permitting issues to regulators and developers. 


\section{TABLE OF CONTENTS}

\section{Executive Summary}

Chapter 1. Introduction and Methodology 1

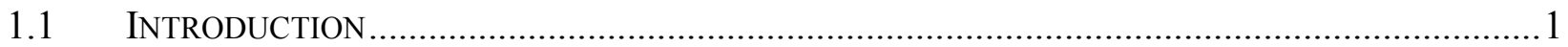

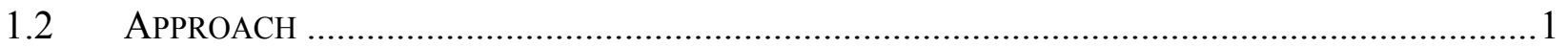

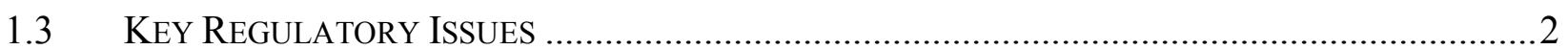

1.4 KEY DG APPLICATIONS AND TECHNOLOGIES ...........................................................

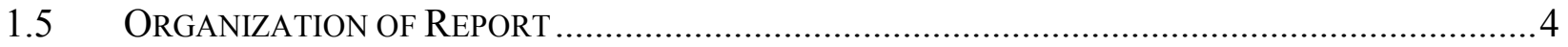

\section{Chapter 2. Overview of Distributed Generation 5}

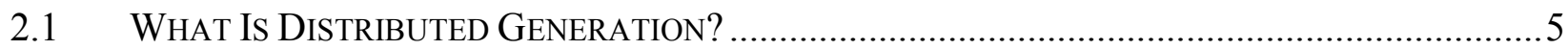

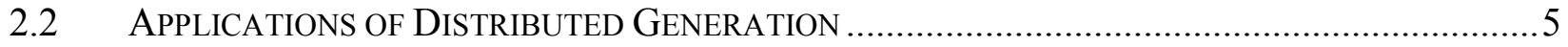

2.2.1 Combined Heat and Power 6

2.2.2 Waste and By-product Fuels 8

2.3 DISTRIBUTED GENERATION TECHNOLOGIES .............................................................

2.4 BENEFITS OF DistRIBUTED GENERATION ................................................................. 10

2.4.1 Economic and Operational Benefits 10

2.4.2 Air Quality Benefits of DG 11

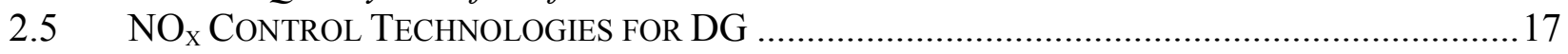

2.5.1 Low-NO $\mathrm{N}_{x}$ Combustion Technologies 17

2.5.2 Post-Combustion $\mathrm{NO}_{x}$ Control Technologies 17

\section{Chapter 3. Air Quality Regulation of Power Generation in the United States 21}

3.1 Federal Laws And Regulations Applicable to Power Generation .......................21

3.1.1 Federal New Source Permits in Attainment Areas 24

3.1.2 Federal New Source Permits in Nonattainment Areas. 25

3.1.3 State Emission Permits for Minor New Source Review 25

3.2 State Distributed Generation Regulations ........................................................25

$\begin{array}{lll}3.2 .1 & \text { California } & 25\end{array}$

$\begin{array}{lll}3.2 .2 & \text { Texas } & 27\end{array}$

$\begin{array}{lr}\text { Chapter 4. Findings } & 29\end{array}$

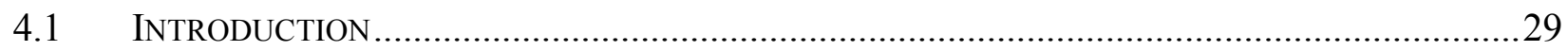

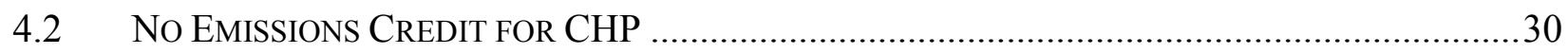

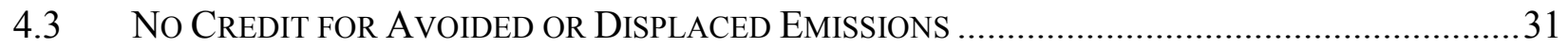

4.4 Complex Case-By-Case Permitting Process Is Incompatible With the ApPlication of SMALL, StANDARDIZED DG TECHNOLOGIES ......................................................... 33

4.5 NO CONSIDERATION OF VERY HIGH UNIT COSTS OF STRINGENT EMISSION LiMITS FOR SMALL, CLEAN GENERATORS ................................................................................. 35

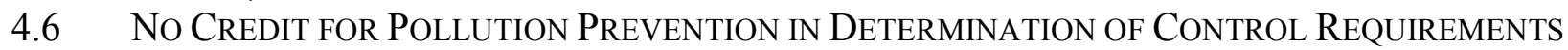


Chapter 5. Recommendations and Conclusions

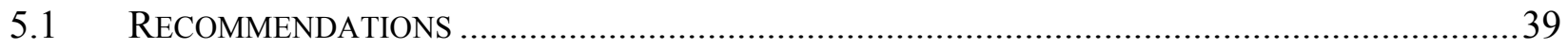

5.1.1 Develop Uniform, Achievable Environmental Standards for DG 39

5.1.2 Provide Credit for CHP 40

5.1.3 Provide Credit for Avoided/Offset Emissions 40

5.1.4 Incorporate Market-based Regulatory Structures 41

5.1.5 Provide Outreach and Training for Regulators and Developers 42

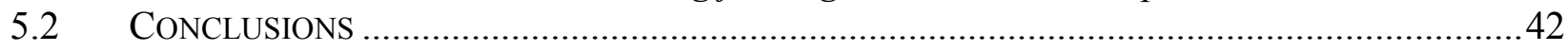

$\begin{array}{ll}\text { Glossary } & 43\end{array}$

\section{List of Tables}

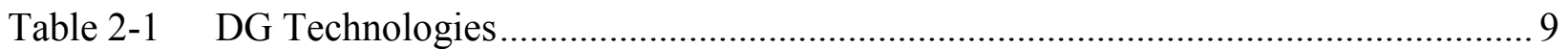

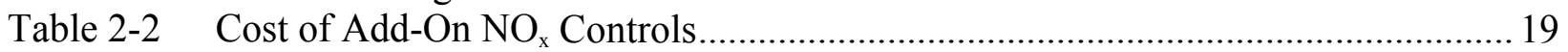

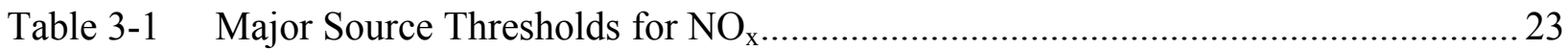

Table 3-2 Potential $\mathrm{NO}_{\mathrm{x}}$ Emissions of DG Technologies.......................................................... 24

Table 3-3 Proposed California 2003 DG Certifications Standards............................................ 26

Table 3-4 Proposed California 2007 DG Certification Standards .............................................. 26

Table 3-5 Texas $\mathrm{NO}_{\mathrm{x}}$ General Permit Limits for Units $<10 \mathrm{MW}$................................................ 27

\section{List of Figures}

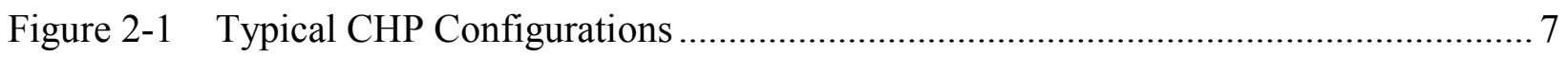

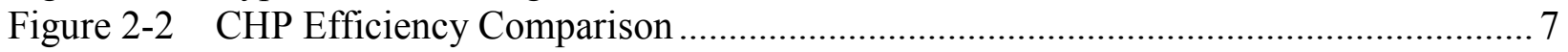

Figure 2-3 $\quad \mathrm{SO}_{2}$ Emissions Comparison............................................................................... 13

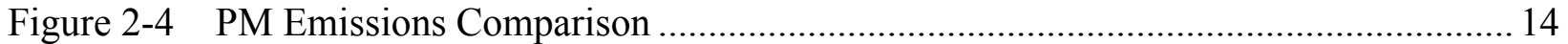

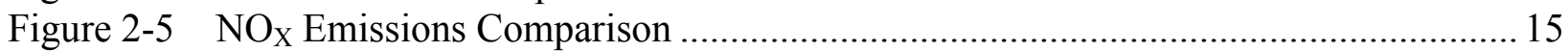

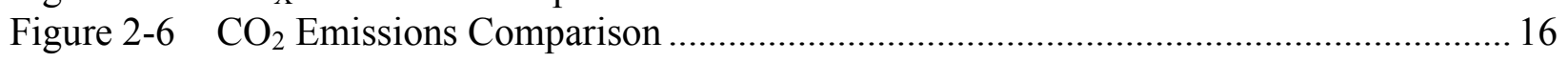

Figure 2-7 Cost Effectiveness of Post-Combustion $\mathrm{NO}_{\mathrm{x}}$ Controls .............................................. 20

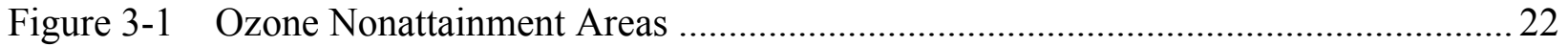




\section{Chapter 1. Introduction and Methodology}

\subsection{Introduction}

This report investigates the effect of air quality permitting on a variety of recent distributed generation (DG) projects and identifies a number of ways in which the present structure and application of air quality regulations are inefficient or inappropriate in their treatment of DG. The report analyzes these issues and presents recommendations for improving the regulatory structure. ${ }^{2}$

DG is generally defined as electricity generation located at or close to the point of use. ${ }^{3}$ This study focuses on small (less than 15 megawatts (MW) per unit) fossil-fueled distributed electric generators and in particular on:

- Gas-fired technologies

- Combined heat and power (CHP) applications

- Technologies with inherently low emissions

- Applications that use waste or byproduct fuels

DG offers users many potential operational, economic, and environmental advantages.

\footnotetext{
${ }^{2}$ While any remaining errors or omissions are those of the authors, the following individuals deserve acknowledgement for their willingness to review the draft report at various stages of its preparation and provide invaluable guidance: Chris James, Connecticut Department of Environmental Protection; John Kelley, GTI; Leslie Witherspoon, Solar Turbines; Shirley Rivera, AESC, Inc; Art Smith, NiSource, Inc.; and Sara Hayes, EEA. Additionally, our thanks go to the many project developers, owners, and regulators who participated in the survey and follow-up interviews, and to Joe Bryson and Luis Troche of the EPA, who spent a great deal of time with us reviewing an earlier draft. Finally, the authors thank Joseph Galdo, DOE Office of Distributed Energy and Electricity Reliability; and Richard DeBlasio and Gary Nakarado of the National Renewable Energy

Laboratory for their support in this project.

${ }^{3}$ The definition of DG is discussed further in Chapter 2.
}

The National Energy Policy issued by the White House in May $2001^{4}$ recognizes the efficiency gains from DG achieved by eliminating electric transmission and distribution losses, use of thermal output for $\mathrm{CHP}$, and integrating on-site energy efficiency and generating capabilities. Much of today's market for DG is driven by needs that cannot be met by central generation, such as emergency generation, reliability, and power quality. Finally, many DG technologies have lower emissions than the average of the central generating grid and can provide an environmental benefit in displacing central generation.

However, it has been claimed by many in the DG industry that environmental permitting is a serious challenge to the deployment of DG technologies. ${ }^{5}$ There is concern that permitting does not appropriately address the environmental impact of a DG project or give credit for the environmental benefits of DG. This report investigates the sources of those concerns and presents specific

recommendations for developing national and state policies that would promote clean DG in a way that is consistent with national and state air quality goals.

\subsection{Approach}

This study analyzed specific DG project case studies to review the current framework of air

\footnotetext{
${ }^{4}$ National Energy Policy, "Reliable, Affordable, and Environmentally Sound Energy for America's Future," Report of the National Energy Policy Development Group, May 2001.

5 "Distributed Generation Challenges: Air Quality, Siting, Permitting," Shirley F. Rivera, Winter 2000-01-Vol. 20, No. 3 Issue of Energy Matters. See DOE Office of Industrial Technologies, Best Practices, online supplement, http://www.oit.doe.gov/bestpractices/energymatters/emextra/ pdfs/63-79_rivera.pdf.
} 
quality permitting requirements applicable to DG and their effect on developing and deploying DG. The first task was to identify recent DG projects from which to develop case studies of environmental regulatory issues. More than 200 industry experts, air regulators, U.S. Department of Energy (DOE) and U.S. Environmental Protection Agency (EPA) staff, and DG project developers were contacted to identify potential case studies. Projects selected for the case studies were required to meet the following criteria:

- Electric capacity less than $15 \mathrm{MW}$ per unit

- Installed after December 31, 1995, or pending installation

- The existence of verifiable information on the project and permitting experience.

The case studies were selected to cover a range of relevant factors, including:

- Key states representing current regulatory status in different regions of the country

- A diverse cross-section of DG technologies and fuel types

- Diverse applications, including CHP, peak shaving, emergency backup, power quality, baseload, and aggregation for wholesale application

- Attainment and nonattainment areas. ${ }^{6}$

Approximately $20 \%$ of the case studies reviewed were eliminated because of a lack of verifiable data. The remaining case studies represent the experiences of 51 specific projects. These initial 51 case studies were developed through detailed telephone interviews with participating project owners, developers, and air quality regulators. The primary use of the pool of 51 cases was to narrow the focus of the investigation to the

\footnotetext{
${ }^{6}$ Nonattainment areas are specific geographic regions that have not met federal regulations for one or more criteria air pollutants. Typically these are metropolitan areas.
}

issues and recommendations determined most significant to DG. The smaller number of cases discussed more fully in the report are used for their illustrative fact patterns. Where the cases are so utilized, key facts of the particular case were verified as appropriate through follow-up telephone interviews, public records, or other means.

While most of the issues and recommendations are an outgrowth and necessary results of the current legal structure of environmental regulation, the cases are also valuable in understanding the impact and nature of the issues raised and the recommendations put forward.

This study is not a statistical sample and does not project the extent of the regulatory issues identified. Rather, it seeks to identify structural issues in the regulation of DG that could be changed to promote environmentally beneficial DG technologies and applications.

\subsection{Key Regulatory Issues}

The analysis identified several key areas of regulatory structure that need to be addressed in order to properly recognize the environmental benefits offered by DG technologies and to properly address the small size and other unique characteristics of DG technologies. These areas are:

- Appropriate treatment of CHP systems.

- Recognition and crediting for avoided and offset emissions (including beneficial use of flared fuels such as landfill gas).

- Regulatory recognition for inherently low-emitting technologies.

- Suitability of case-by-case permitting for DG projects.

- Appropriate treatment of control costs for very small systems. 
Most of these issues were identified in state "minor source" permitting in nonattainment areas. While nonattainment areas constitute a small geographic fraction of the United States, they comprise major markets for DG. Moreover, the importance of these permitting practices is expected to expand for at least two reasons:

- The areas of nonattainment will be expanded to cover more of the nation over the coming years with the implementation of the new 8-hour ozone and fine particulate matter standards.

- With the expected dramatic increase in the use of DG, environmental regulators have already confirmed their increasing concern for developing new or additional approaches to the environmental regulation of DG. ${ }^{7}$

All these issues are discussed in the following chapters.

\subsection{Key DG Applications and Technologies}

This analysis identified three DG applications/technologies for which air quality regulation is particularly ineffective in recognizing the environmental benefits and unique characteristics of DG. The treatment of these applications and technologies is the primary focus of this report.

- CHP applications - CHP is perhaps the most readily available and costeffective means of reducing emissions and energy consumption through increased energy efficiency (see Section 2.2). However, because CHP involves multiple energy applications and displaces multiple conventional

\footnotetext{
7 "Proceedings Energy \& the Environment: The Second National Conference of Policy Makers Working Together." September 24-27, 2000, St. Louis, MO. See http://www.naseo.org/events/other/stlouis/
}

energy generating sources, conventional air quality permitting does not recognize the environmental benefits that CHP provides. Ensuring that air quality permitting recognizes and encourages CHP is an important policy goal.

- Applications that use waste or byproduct fuels-Many DG technologies use waste or by-product fuels that are available at the point of use. Using waste fuels is valuable from an energy perspective. In addition, using waste and by-product fuels to produce useful output through DG often replaces waste incineration that produces air emissions with no useful output. Air quality regulations often do not give credit for this emission displacement and thus do not accurately reflect the benefits of using these fuels for DG technologies.

- Technologies with inherently low emissions - There is widespread agreement that it is economically and environmentally preferable to avoid creating emissions (pollution prevention) rather than cleaning them up after they are created. Most DG technologies are designed to be inherently low emitting because the cost and complexity of add-on controls makes them impractical or uneconomical. However, many air quality regulations have traditionally focused on add-on emission control technologies and do not yet recognize inherently low-emitting technologies. This approach is counterproductive and at odds with stated national policies regarding energy efficiency and pollution prevention. Recognizing the value of inherently low-emitting technologies is an important policy goal and is important to the economic viability of DG technologies. 


\subsection{Organization of Report}

Chapter 2 of this report provides background information on DG technologies, their emission characteristics, and potential benefits. Chapter 3 provides background on federal and state regulatory requirements for DG technologies. Chapter 4 presents the findings of the report and illustrates the issues addressed with case study examples. Chapter 5 provides recommendations for ways in which air quality regulations could be updated to recognize the characteristics and benefits of new, small DG technologies. 


\section{Chapter 2. Overview of Distributed Generation}

\subsection{What Is Distributed Generation?}

There are several definitions of distributed generation in common use. Most definitions include some aspect of "generation at or near the point of use." Some definitions would abbreviate this to "on-site generation," but this is too narrow as the following two examples show. University campus CHP systems, for example, use the generated electricity locally, but not all at the site of generation. Another example is a small generator installed at a utility substation to alleviate transmission and distribution limitations; this is also DG, but the electricity generated is not used "on-site".

Size can be another confusing aspect of DG. Although much of today's commercial DG focus is on small DG (less than $10 \mathrm{MW}$ ), there are many large, on-site industrial power generation systems that make up the greatest share of DG in the United States. Industrial CHP facilities providing on-site generation of electricity in the paper, steel, refining, and chemicals industries have been in use for many years.

For the purposes of this report, the authors define DG as small-scale electricity generation interconnecting with the electric grid at the distribution voltage at or near the point of use. This definition still includes large industrial generating facilities. However, larger facilities (greater than $15 \mathrm{MW}$ per unit) are not of great interest for this report. Because they are large facilities, they are appropriately subject to the standard environmental permitting procedures. While there may be controversial issues related to their permitting, they are similar to the issues raised by many other operators and developers of large emission sources. This report also excludes renewable DG technologies, which except for biomass power plants, are not subject to air quality permitting requirements ${ }^{8}$.

This report focuses on small fossil-fueled DG technologies (less than $15 \mathrm{MW}$ per unit). It is the development and commercialization of these smaller scale technologies that is raising new environmental permitting issues. The term DG, then, when used in the context of the permitting process in this report refers to fossil-fueled DG less than 15 MW per unit.

\subsection{Applications of Distributed Generation}

There are a variety of drivers for the increased interest and development of DG. The fundamental driver is that there are certain markets in which small, on-site electric generators can provide services or economic value that is not provided by central generation. One example is a form of DG that actually pre-dates the term "DG"emergency backup generators. ${ }^{9}$ These on-

\footnotetext{
${ }^{8}$ Biomass applications are the one renewable technology that may be subject to air emission permitting requirements. They are not included here because biomass technologies are typically larger than the applications of interest in this study and thus have different permitting issues. The exception is landfill gas, which is included in this report.

${ }^{9}$ In fact, specific laws, codes, and standards require the provision of emergency generators. For example, the National Electrical Code 517-13, requires all hospitals and critical care facilities to have backup power systems that start automatically and are up and running at full capacity within 10 seconds after power failure. The National Building Code of the National Fire Protection Association requires high-rise buildings to have immediately available emergency power generation for elevators. This ensures that passengers will not be stranded on elevators on upper floors in the event of a fire or other emergency. States typically adopt the national codes. For example, Section 403.8 of the Massachusetts State Building Code (MSBC), 6th Edition, states that standby power is required for elevators in high rise buildings, and that the power shall be
} 
site generators provide power when grid power is disrupted and so, by definition, provide a service not met by the grid. . In some regions, high local electricity prices make on-site generation less expensive than purchasing electricity from the grid. CHP, where the high systems efficiencies can be realized, is an example of a DG application that can be economically attractive compared with bulk power from the grid. Peak shaving is another well-established application for on-site generation to reduce electricity costs.

In recent years, the increased use of electronic equipment with limited tolerance to variations in power quality has increased interest in onsite generation for power quality and reliability at commercial and industrial facilities

Electric industry restructuring has increased the opportunities for DG by increasing the flexibility with which electricity customers can access the electric grid and apply new generation technologies. It has also created new opportunities for selling power to the grid or using on-site generation to reduce load at times of high demand in return for payment from the grid operator.

New interest in DG has been spurred by the development of technologies that provide new options for very small, on-site generation. Microturbines, fuel cells, and improvements in combustion turbines and reciprocating engines all present the potential for more flexible, more efficient, cleaner, and lower cost DG applications.

\subsubsection{Combined Heat and Power}

The use of CHP to simultaneously generate thermal and electrical energy on-site is another highly efficient, cost-effective DG application that is attracting increased interest. In conventional separate generation of electricity, roughly two-thirds of the input thermal energy

provided for at least one elevator to serve all floors and be transferable to any elevator. is exhausted to the environment. In the conventional generation of electricity without the recovery of the waste heat from the combustion process, roughly two-thirds of the input thermal energy is exhausted to the environment. In CHP applications, however, much of this otherwise wasted thermal energy is used on-site for processing, heating, cooling, or other applications. The engine, turbine, or fuel cell is used to generate electricity, and thermal energy is recovered from the exhaust or cooling flows to provide useful thermal energy.

\section{Old Boilers Are an Opportunity for CHP}

Most of the installed U.S. base of large industrial and commercial boilers are more than 30 years old. As these boilers are retired, there is a window of opportunity to replace steam-only generation with CHP. If this window is missed, it will be another 30 years or more before there is a chance to replace the boilers through attrition.

U.S. Industrial Boiler Sales - 1964 - 1999

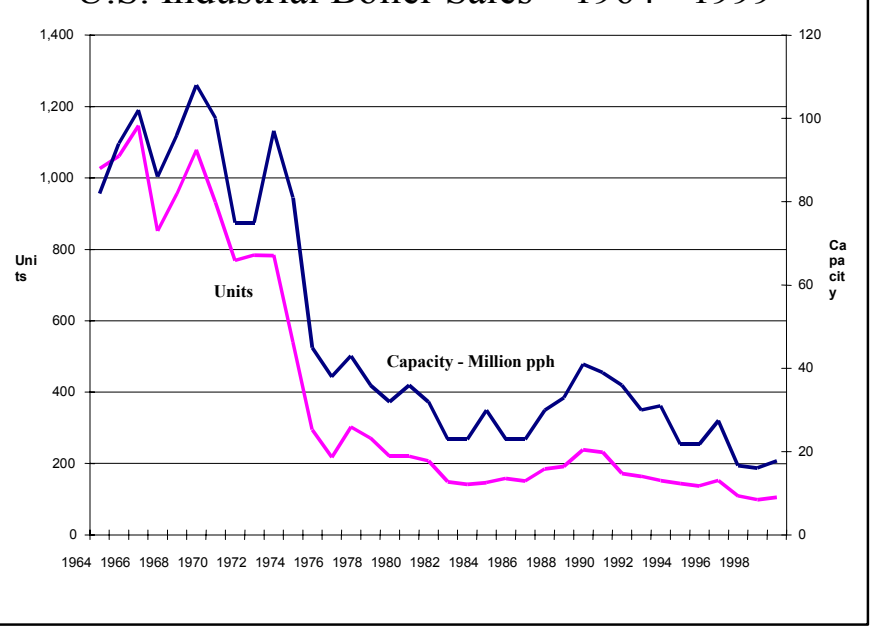

Data Source: ABMA

Figure 2-1 shows typical configurations for CHP applications. The average efficiency for U.S. central station generation is estimated at about $33 \% .{ }^{10}$ The combination of conventional electric generation and steam generation is about $45 \%$ efficient, as shown in Figure 2-2. CHP systems typically ${ }^{10}$ EIA Annual Energy Review 2000, published August
2001 page 217 and notes at page 248 . 
are $60 \%$ to $80 \%$ efficient overall, and some applications can be more than $90 \%$ efficient. Because CHP is more efficient, it uses less fuel and emits fewer emissions than conventional separate generation. New CHP facilities also often replace older, higher emitting units, further reducing the overall emissions.

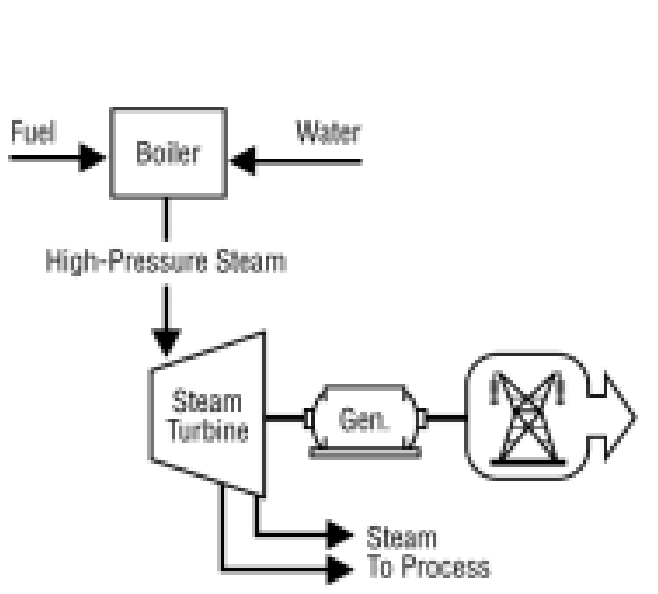

\section{Steam Boiler/ Steam Turbine:}

Gas Turbine Or Engine/Heat Recovery Unit:
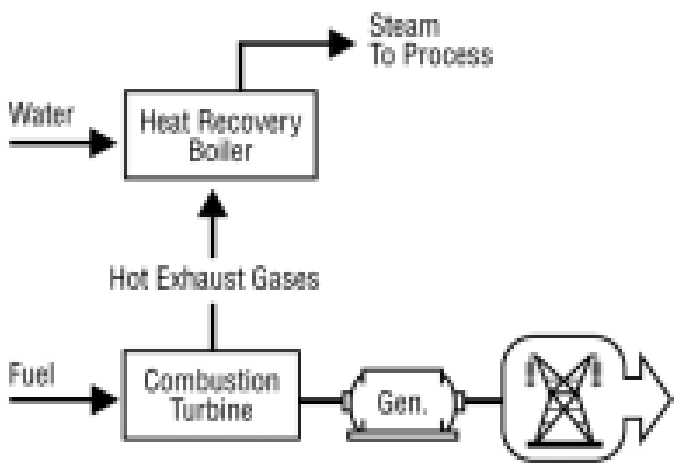

Figure 2-1

Typical CHP Configurations

Conventional

Generation:
Combined Heat \& Power:

1 MW Natural Gas

Reciprocating Engine

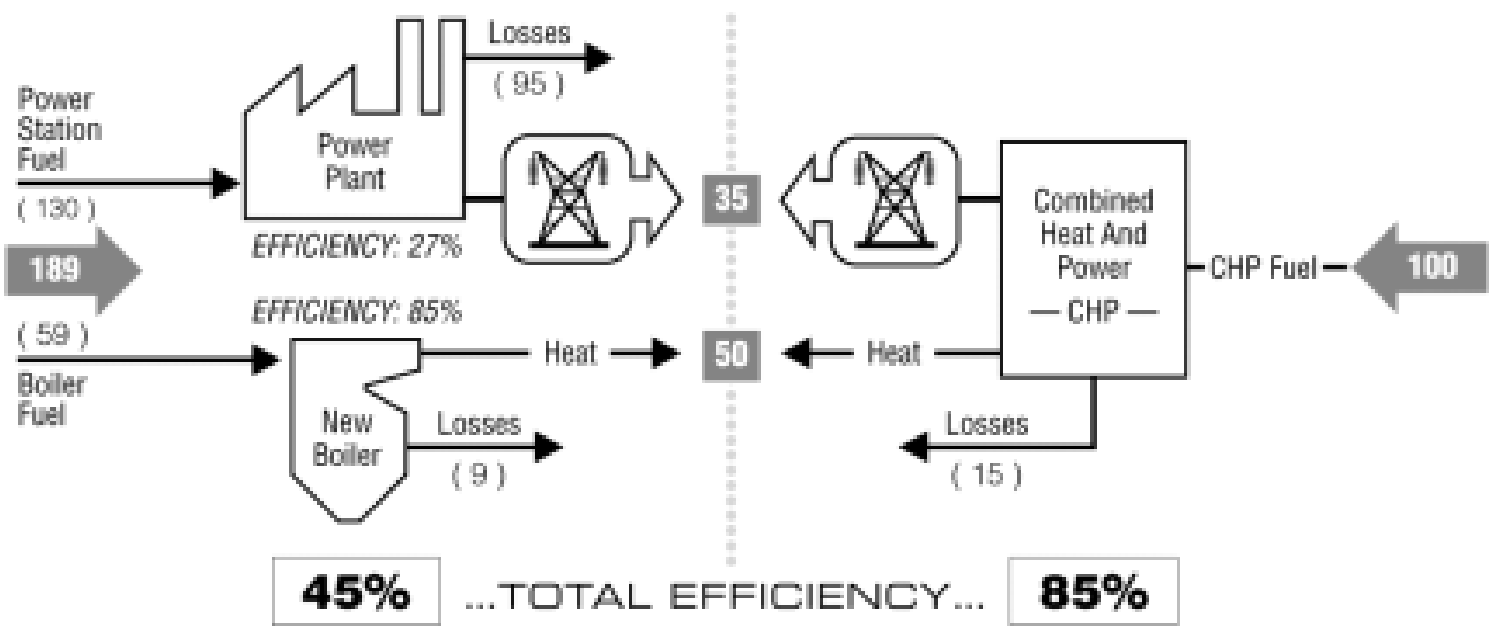

Figure 2-2

CHP Efficiency Comparison 


\subsubsection{Waste and By-product Fuels}

DG systems can be designed to use waste or by-product fuels available on-site that would otherwise be flared with no useful output or otherwise disposed of. Waste and by-product fuels such as wood waste from the wood, paper, and furniture industries, refinery gas from the petroleum refining industry and process by-products from the chemicals industry are common fuels for DG because they represent a source of "free" energy.

Landfill gas is another example of by-product fuel. Landfill gas is composed largely of methane, a potent global heating gas, which is often flared to avoid this and other negative impacts. ${ }^{11}$

However, the flaring creates products of combustion, including $\mathrm{NO}_{\mathrm{x}}$ and creates no useful output. If the landfill gas is used to generate electricity, the generator emits $\mathrm{NO}_{\mathrm{x}}$ but the emissions from flaring are eliminated and there is a useful output. The avoided

\footnotetext{
${ }^{11}$ For example, the California Air Resources Board, in its "Guidance for the Permitting of Electrical Generation Technologies" issued November 15, 2001, providing the following information and guidance regarding the use of landfill gases for electric generation. "Waste gas refers to gases generated at landfills or in the digestion of solid materials at waste water treatment plants. Both reciprocating engines and gas turbines have been used to generate electricity from waste gas. The recently promulgated NSPS (40 Code of Federal Regulation 60, subpart CC and WWW) requires most landfills to collect and destroy the gas produced by the landfill. At a minimum, landfill operators are required to flare the landfill gas. Many landfills have opted to develop energy projects that allow for the generation of electricity while disposing of the gas. Generally, large reciprocating engine generator sets, typically larger than $800 \mathrm{KW}$, have been used for these applications. In a few cases, gas turbines have been used instead of reciprocating engines... Overall, this category of using waste gas to generate power will have the most difficulty in attaining the goal of equivalent emissions to a central station power plant equipped with BACT. However, this difficulty should be balanced with the recognition that historically waste gases were either not collected or were flared without controls." (emphasis added)
}

flaring emissions are rarely reflected in setting the emission limits, however.

\subsection{Distributed Generation Technologies}

Although DG includes very large (greater than $50 \mathrm{MW}$ ) generators, the primary recent interest in DG is in small generators (less than 15 MW per unit). DG includes a wide variety of technologies and fuels, and small DG technologies include both renewable and fossil fuel technologies. Table 2-1 lists many of the most common DG technologies and their characteristics. Renewable energy technologies are not addressed in this report. ${ }^{12}$ The primary fossil-fuel DG technologies relevant to this study are:

- Reciprocating engines-Reciprocating engines are currently the most common technology in use for DG. They are available in sizes from a few $\mathrm{kW}$ to multiple MW and are used in a wide range of applications from standby/emergency use to baseload/CHP. Compression ignition or diesel engines are the most common reciprocating engine technology, but their application is limited in many cases due to high $\mathrm{NO}_{\mathrm{x}}$ and particulate emissions. Spark ignition natural gas engines are of greater interest in this study due to their lower emissions and resulting wider applicability. Gas engines are further subdivided into lean-burn and rich-burn engines. The same spark ignition technology can by used with landfill or digester gas and certain industrial by-product gases.

\footnotetext{
${ }^{12}$ Renewable energy technologies such as wind turbines and solar cells, in and of themselves, do not produce air emissions, so should be largely exempt from air emission permits. For DG applications, however, they are often paired with fossil-fuel technology to provide continuous service. Biomass combustion, on the other hand, while similar to fossil fuels in air emissions, is less likely to use standard, offthe-shelf, equipment or standard fuels, so also likely warrants different treatment.
} 
Table 2-1

DG Technologies

\begin{tabular}{|c|c|c|c|c|c|}
\hline Technology & $\begin{array}{c}\text { Size Range } \\
(\mathrm{kW})\end{array}$ & $\begin{array}{c}\text { Installed Cost } \\
(\$ \mathrm{~kW})\end{array}$ & $\begin{array}{l}\text { Heat Rate } \\
(\mathrm{Btu} / \mathrm{kWh})\end{array}$ & $\begin{array}{c}\text { Approximate } \\
\text { Efficiency } \\
(\%)\end{array}$ & $\begin{array}{c}\text { Variable } \\
\text { O\&M } \\
(\$ / k W h)\end{array}$ \\
\hline Diesel Engine & $1-10,000$ & $350-800$ & 7,800 & 45 & 0.025 \\
\hline $\begin{array}{l}\text { Natural Gas } \\
\text { Engine }\end{array}$ & $1-5,000$ & $450-1,100$ & 9,700 & 35 & 0.025 \\
\hline $\begin{array}{l}\text { Natural Gas } \\
\text { Engine w/CHP }\end{array}$ & $1-5,000$ & $575-1,225$ & 9,700 & 35 & 0.027 \\
\hline Dual Fuel Engine & $1-10,000$ & $625-1,000$ & 9,200 & 37 & 0.023 \\
\hline Microturbine & $15-60$ & $950-1,700$ & 12,200 & 28 & 0.014 \\
\hline $\begin{array}{l}\text { Microturbine } \\
\text { w/CHP }\end{array}$ & $15-60$ & $550-1,700$ & 11,000 & 28 & 0.014 \\
\hline $\begin{array}{l}\text { Combustion } \\
\text { Turbine }\end{array}$ & $300-10,000$ & $700-2,1000$ & 11,000 & 31 & 0.024 \\
\hline $\begin{array}{c}\text { Combustion } \\
\text { Turbine } \\
\text { w/CHP }\end{array}$ & $300-10,000$ & $700-2,100$ & 11,000 & 31 & 0.024 \\
\hline Fuel Cell & $100-250$ & $5,500+$ & 6,850 & 50 & $0.01-0.05$ \\
\hline Photovoltaics & $0.01-8$ & $8,000-13,000$ & -- & N/A & 0.002 \\
\hline Wind turbine & $0.2-5,000$ & $1,000-3,000$ & -- & N/A & 0.010 \\
\hline
\end{tabular}

Source: Federal Energy Management Program

- Combustion turbines-Combustion turbines, also referred to as "gas turbines," can operate on natural gas, landfill gas, or distillate/diesel fuel. Combustion turbines are available in sizes from just below $1 \mathrm{MW}$ and higher and are best suited to peaking and baseload operation. Combustion turbines are on the large end of the DG spectrum and typically require more sophisticated operating personnel. They are well suited to CHP applications.

- Microturbines-Microturbines are very small combustion turbines, typically with capacities of less than 500 kilowatts $(\mathrm{kW})$. Common sizes today are in the $30 \mathrm{~kW}, 60 \mathrm{~kW}$, and $150 \mathrm{~kW}$ range. Microturbines have relatively low efficiency-less than $30 \%$. Their emissions are comparable to or lower than those of standard combustion turbines. Microturbines are a new technology that is just entering the

commercial market. Price and performance characteristics have yet to be firmly established.

- Fuel cells-Fuel cells are electrochemical generators rather than heat engines. They have no moving parts and no combustion. Because of this, they have very low emissions. ${ }^{13}$ There are several different fuel cell technologies of which only one, the phosphoric acid fuel cell, is currently commercially available. While it has very low emissions, fuel cells are currently bulky and very expensive. Newer fuel cell designs may be available in the near future, but their performance and cost have yet to be established on a commercial basis. Nevertheless, there is great

\footnotetext{
${ }^{13}$ The fuel cell itself uses hydrogen as its fuel and has very low emissions. Most current fuel cells, however, must convert conventional fossil fuel to a hydrogen-rich fuel. The reformer used to process the fuel is the source of most of the fuel cell air emissions.
} 
anticipation of the potential benefits of fuel cell technology. Fuel cells are expected to be available in a range from a few $\mathrm{kW}$ to a few $\mathrm{MW}$.

Interest in these technologies is increasing because of recent technology advances and because they match the changing needs of customers with electric loads in this smaller size range. Most DG users are, by definition, in some business other than power generation. ${ }^{14}$ They are industrial, commercial, institutional, or private residential entities that find it beneficial to generate their own electricity as part of their business. However, they may not have skilled employees available to devote to operating and maintaining the power generation. Thus, it is highly desirable for DG technology to be simple, self-contained, and easy to maintain and operate. For smaller applications, the industry goal is for DG to be "as simple and reliable as a refrigerator." DG technologies are accordingly designed to be pre-packaged, self-contained, standardized systems.

The nature of the emerging DG market also places a premium on low capital cost. Low initial cost is important for favorable project economics, but it is also important because DG is typically a discretionary investment for businesses that have many competing needs for capital. All these factors lead to the need to mass-produce standard DG equipment. The future viability of the newer technologies, such as fuel cells and microturbines, is widely believed to hinge on the potential to massproduce large quantities at a lower capital cost. Diesel and gas engine generator technologies already benefit from the large production volumes of related vehicle engines. Combustion turbines are manufactured at lower volumes but still on a standardized, package basis rather than the individual design approach used for larger

\footnotetext{
${ }^{14}$ The primary exception is energy service companies (ESCos) which provides third-party development and management of some DG facilities.
}

electric generating technologies. The need for standardized equipment to meet the DG market has important implications for meeting environmental requirements discussed below.

\subsection{Benefits of Distributed Generation}

\subsubsection{Economic and Operational Benefits}

The potential economic and operational benefits of DG have been discussed in a number of reports and other publications. ${ }^{15,16,}$ 17

15 "The Role of the Federal Government in Distributed Energy," 2002, Edward A. Reid, Jr., Nat Treadway, CAEM, Distributed Energy Task Force, http://www.caem.org/ 16 "The Role of the Federal Government in Distributed Energy," 2002, Edward A. Reid, Jr., Nat Treadway, CAEM, Distributed Energy Task Force, http://www.caem.org/

${ }^{17}$ See, for example, the Gas Research Institute, "Benefits of Distributed Generation"

http://www.gri.org/pub/solutions/dg/benefits.html, "Distributed Generation: Policy Framework for Regulators" An Arthur D. Little White Paper, 1999

http://www.adlittle.com/management/services/utilities/article s/PolicyFramework.pdf, for a list of benefits to the utility offered at the California Energy Commission's Workshop to Develop a Strategic Plan for Distributed Generation (Held on February 5, 2002), Susan Horgan, Distributed Utility Associates "Today's Central Utility - Tomorrow's Distributed Utility?" which includes, dispatchable peak demand reduction, Maximum use of standby capacity through safe parallel operation with the utility grid, Cost-effective solution consistent with least cost planning emphasis, Improved system load factor, Enhanced voltage stability and avoided line losses during heavy-load conditions, and Improved customer relations. For a relatively technical and detailed look at the benefits to the distribution system itself, see, Distributed Generation Case Studies For Permit Streamlining and the Impact Upon Transmission and Distribution Services," recently prepared for the California Energy Commission by Onsite Energy Corp., Jan 2002 which includes the following at page 22: 1) Capacity support; 2) Contingency capacity support; 3) Reduction of losses; 4) Voltage support; 5) Voltage regulation; 6) Power factor control; 7) Phase balancing; and 8) Equipment life extension. For a presentation by Thomas Casten, one of the nation's pioneer advocates for CHP and distributed generation see Energy to the US (and planet earth) DER- The Power to Choose," November 28, 2001, Thomas R. Casten, Chairman \& CEO, Private Power, November 28, 2001 available at http://www.eren.doe.gov/der/pdfs/conf_01/casten_der_pwr_c hoose.pdf 
The principal benefits being realized today include the following:

- Reliability. Credit card processing centers, internet services, and other key elements of our information-based economy can require $99.9999 \%$ reliable electric service or better. Disruptions in electric service can be extremely expensive in terms of lost business or disruptions in their customers' business activities. Since the grid provides only $99.9 \%$ reliability, which is sufficient for most utility customers, businesses requiring higher reliability have relied on distributed energy resources, particularly, DG and electric storage to provide the level of reliability they require.

\begin{tabular}{|c|c|}
\hline \multicolumn{2}{|c|}{$\begin{array}{l}\text { The Value of Reliability } \\
\text { A recent study }{ }^{15} \text { found that the nation's industrial } \\
\text { and "digital economy" companies collectively } \\
\text { lose } \$ 45.7 \text { billion per year to power outages. This } \\
\text { enormous value becomes more understandable } \\
\text { when one considers the following valuation of } \\
\text { downtime in specific industries: }\end{array}$} \\
\hline Industry & Cost of Downtime \\
\hline Cellular communications & $\$ 41,000 / \mathrm{hr}$ \\
\hline Telephone ticket sales & $\$ 72,000 / \mathrm{hr}$ \\
\hline Credit card operations & $\$ 2,580,000 / \mathrm{hr}$ \\
\hline Brokerage operations & $\$ 6,480,000 / \mathrm{hr}$ \\
\hline
\end{tabular}

- Power Quality. Manufacturers with sensitive processes, such as semiconductor manufacturing or plastic injection molding, or numerically controlled operations, can lose entire production runs if the voltage levels or frequency of the power in the plant fluctuate. ${ }^{18}$ Again,

\footnotetext{
18 "The Cost of Power Disturbances to Industrial and Digital Economy Companies," Lineweber and McNulty, Primen for EPRI. Power "quality" is the term most often used for relatively short term power disturbances such as harmonics (harmonics result from distortions to the voltage and/or current sine waves and are commonly caused by, industrial
}

the levels of voltage or frequency fluctuations that cause large economic loss to these industries may not even be noticeable to the average customer and are beyond the level of power quality the utility provides. And, again, DG is meeting the need for power quality in ways that the central grid cannot.

- Reduced Cost. Especially in areas where electricity prices are high, CHP and peak shaving applications of DG can compete favorably with the cost of bulk power from the grid. As an alternative to bulk power, DG can reduce the load that the grid serves and contribute to stabilizing electricity prices.

- Inherent Security Advantages. Without the dependence on hard-toprotect transmission and distribution facilities, and because of their dispersed nature, DG has clear advantages in reducing security concerns and vulnerabilities. Renewable distributed technologies have additional security advantages based on their fuel independence.

\subsubsection{Air Quality Benefits of DG}

Determining whether DG will increase or reduce air emissions is difficult for several reasons:

- There are a wide range of DG technologies and an even wider range of emissions characteristics - from zero-emission renewables to diesel engines that emit relatively high levels of certain pollutants. The technologies

\footnotetext{
processes, certain electronic loads, and wiring connections), surges (Surges are caused by over-voltages resulting from lightning, switching on the utility power system and other causes), and sags (Sags are under-voltages on the power system and commonly caused by power failures, downed lines, utility recloser operations, and storms.) Reliability is the term used for longer disturbances or "interruptions" where the issue is not the quality of the wave form of the power flow, but the lack of power flow.
} 
upon which this report focuses emit relatively low levels of these pollutants.

- There are as yet no universal or consistent environmental standards regulating DG technologies to serve as a benchmark. The air emissions from central station power plants, with which DG technologies could be compared, vary widely as well.

- The potentially enormous long term, indirect impact of DG in enabling significantly more, and likely more innovative, CHP applications, stemming from the drastically increased number of sources near potential CHP uses, is extremely hard to quantify.

Nevertheless, except for $\mathrm{NO}_{\mathrm{x}}$ and particulate emissions from diesel engines, DG technologies generally have lower air emissions than the average of central station generation. To the extent installations apply $\mathrm{CHP}$, the environmental advantage of DG will be even greater. Although some prefer to use the cleanest fossil energy generating technology - combined cycle gas turbines with post combustion emission controls - as a benchmark, the average of all central generation including zero-emitting renewables and nuclear generation is a reasonable starting point for the comparison of DG emissions. In either case, the central station emissions should be increased by $9 \%$ to account for the effect of line losses.

Figures 2-3 through 2-6 compare the average emissions of central station generation with the primary small DG technologies examined in this study:
- Natural gas and diesel engines

- Small combustion turbines

- Microturbines

- Fuel cells

Specific technology emissions data were compiled from manufacturers' data. Except for the rich burn gas engine with three-way catalyst, the emissions for DG technologies are without add-on emission control devices. Average (all central station) emission data are based on EPA data on central station emissions.

Chapter 3 provides a detailed discussion of air quality regulations that affect DG. In summary, however, combustion-based DG technologies produce four pollutants that are of primary regulatory importance today and one greenhouse gas that may be important in the future:

- Sulfur dioxide $\left(\mathrm{SO}_{2}\right)$

- Particulate matter (PM)

- Carbon monoxide (CO)

- Nitrogen oxides $\left(\mathrm{NO}_{\mathrm{x}}\right)$

- Carbon dioxide $\left(\mathrm{CO}_{2}\right)$

Sulfur Dioxide $-\mathrm{SO}_{2}$ emissions are a direct function of sulfur in the fuel. DG technologies fueled by natural gas do not produce enough $\mathrm{SO}_{2}$ to warrant regulation. Some diesel-fueled technologies may have fuel sulfur content limits, but $\mathrm{SO}_{2}$ control technologies are not usually required. Some landfill gas systems may require pretreatment to remove sulfur, though this is as much for operational as for air quality reasons. 


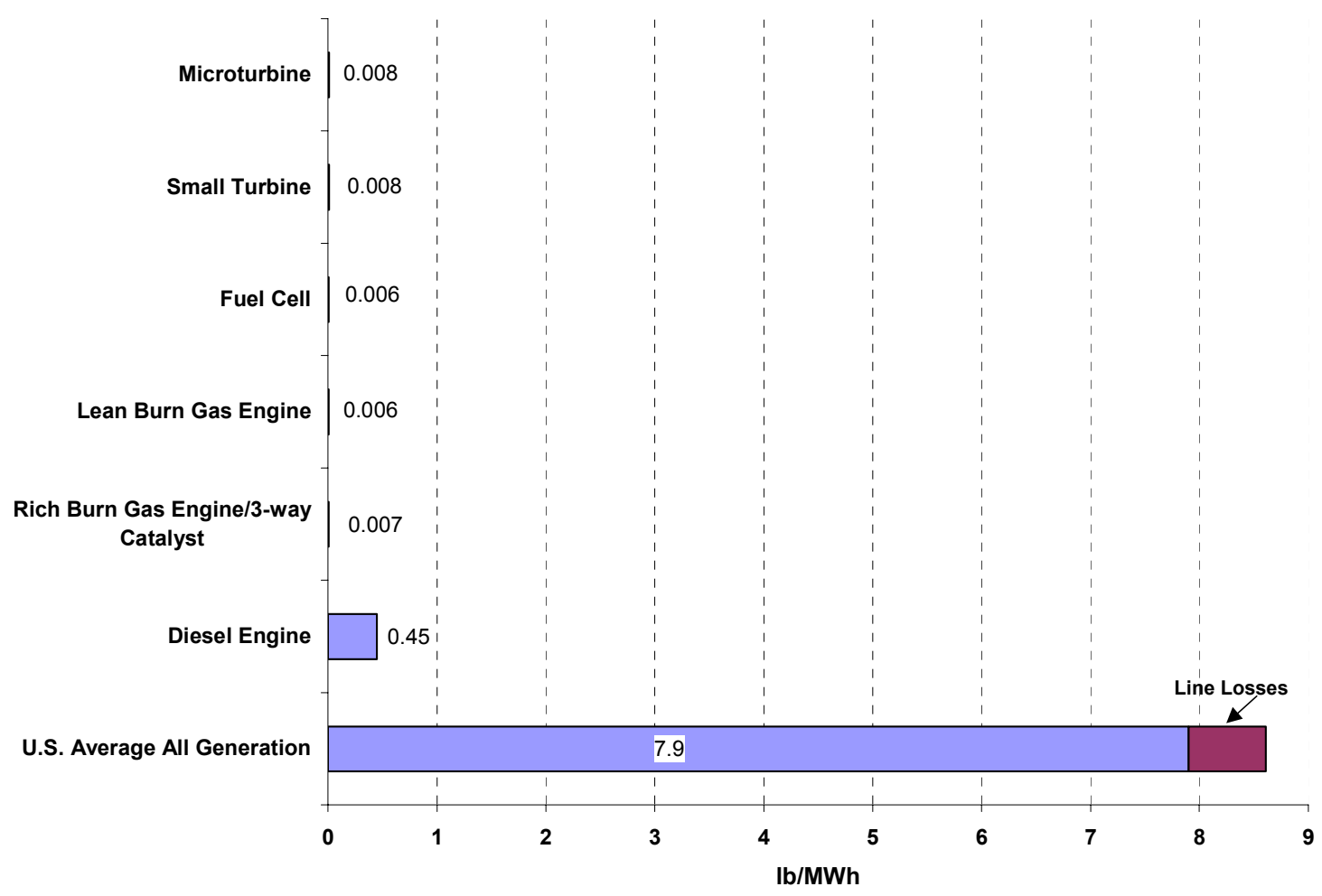

Figure 2-3

$\mathrm{SO}_{2}$ Emissions Comparison

Figure 2-3 shows that the $\mathrm{SO}_{2}$ emissions from DG technologies are much lower than the $\mathrm{SO}_{2}$ emissions from the average of central station power plants. The emissions from the gas technologies are more than 1000 times lower. Even the emissions from the diesel technologies are 10 times lower than average of central station plants.
Particulate Matter-The primary DG technology of concern with regard to particulate emissions is the diesel engine. Diesel particulates are regulated in their own right for highway and non-road engines. Several states may also designate diesel particulates as hazardous air pollutants. (California has already made this designation.) 


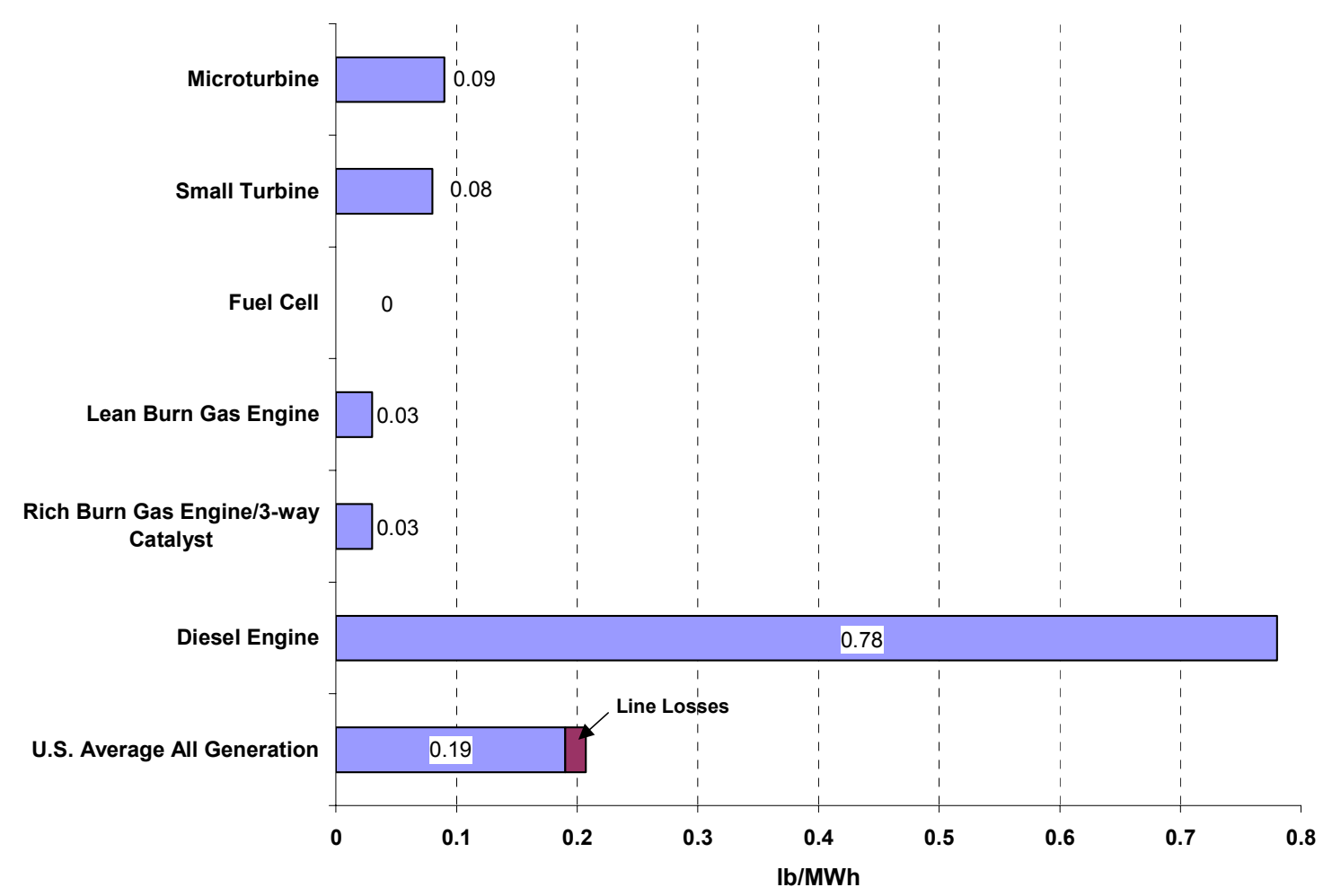

Figure 2-4

PM Emissions Comparison

The different sizes and types of particulates create some inconsistencies in comparing technologies. Nevertheless, as Figure 2-4 shows, DG technologies other than diesel have particulate emissions less than half the central station average. Particulate emissions from DG technologies other than diesels are low enough that they are not usually an issue.

New regulations, however, are being developed by the EPA to address very fine particulates (less than 2.5 micron diameter or $\mathrm{PM}_{2.5}$ ). These very fine particulates are not the ash and unburned fuel components of larger particulates but are sulfates, hydrates, and other combustion products that may be more significant in the combustion products of gas technologies. The new regulations could create PM control issues for more DG technologies in the future.

Nitrogen Oxides - Control of $\mathrm{NO}_{\mathrm{x}}$ emissions is a significant environmental issue for most
DG technologies. Although $\mathrm{NO}_{\mathrm{x}}$ emissions are partially a function of fuel characteristics, combustion temperature and other aspects of combustion design are the primary determinants of $\mathrm{NO}_{\mathrm{x}}$ formation. To reduce $\mathrm{NO}_{\mathrm{x}}$ emissions, one can either modify the combustion process or add post-combustion controls. For the same reasons discussed in Section 2.3-that DG technologies need to minimize capital cost and complexity in order to be successful - the primary focus for DG technology developers has been on minimizing the formation of $\mathrm{NO}_{\mathrm{x}}$ through basic combustion design rather than with addon equipment.

Figure 2-5 shows that DG technologies vary more in their $\mathrm{NO}_{\mathrm{x}}$ emission levels than they do for the other emissions of concern. Still, all of the DG technologies except diesel engines have much lower $\mathrm{NO}_{\mathrm{x}}$ emissions than the U.S. average for central station plants. 


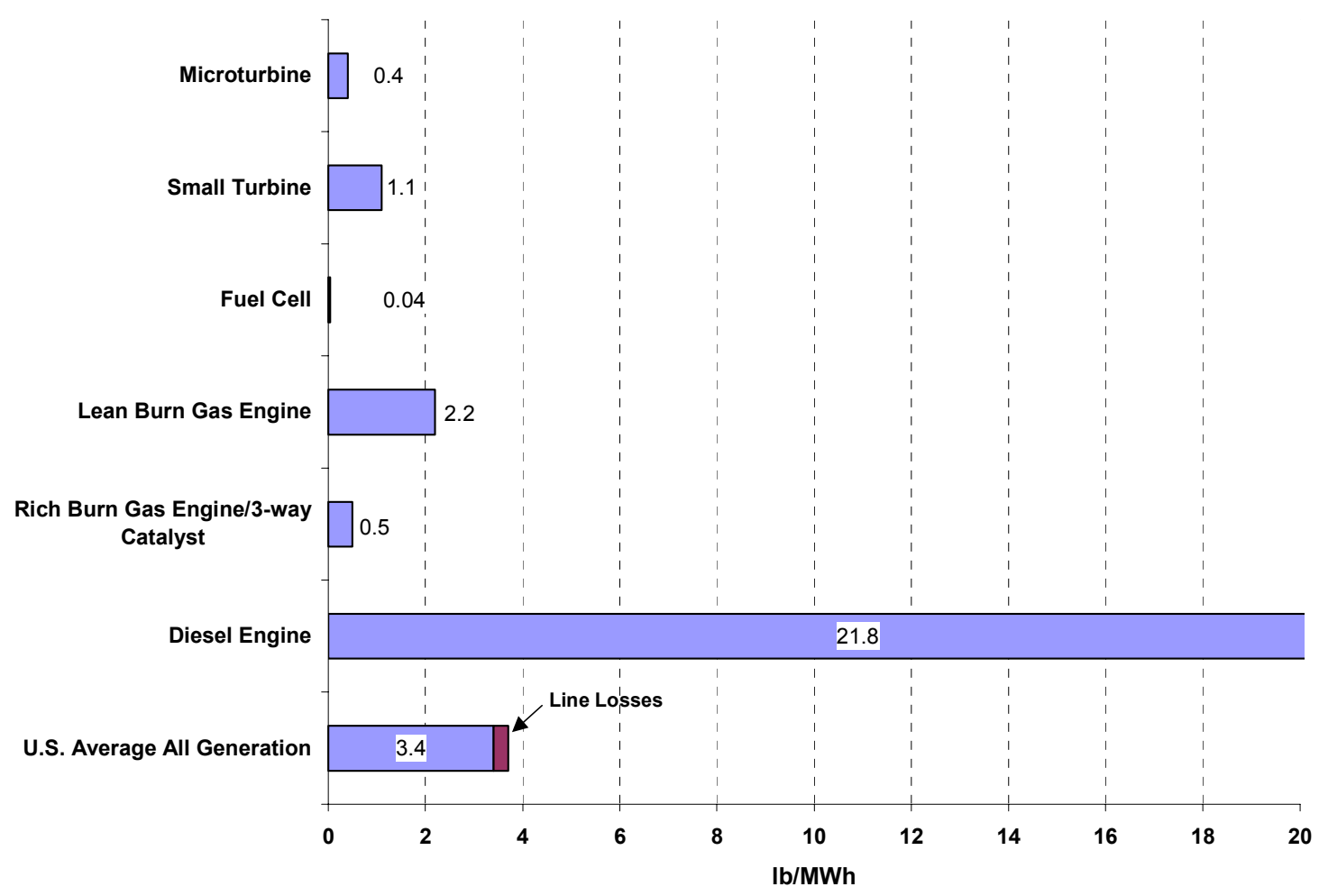

Figure 2-5

$\mathrm{NO}_{x}$ Emissions Comparison

Carbon Dioxide-Although they are not currently regulated at the Federal level, $\mathrm{CO}_{2}$ emissions are starting to be regulated at the state and regional levels. Figure 2-6 shows that the $\mathrm{CO}_{2}$ emissions of DG technologies are comparable to or lower than the average grid emissions. DG technologies generally use relatively low carbon fuels (gas or diesel). However, the grid average includes a large amount of nuclear- and hydro-generated power that creates no $\mathrm{CO}_{2}$ emissions.

Overall Air Emissions - The comparisons in Figures 2-3 to 2-6 show that DG technologies generally have lower air emissions than the average of central station generators. The primary exception is the $\mathrm{NO}_{\mathrm{x}}$ and particulate emissions from diesel engines. To the extent that generation from DG installations using technologies other than diesels displaces existing central station generation, air emissions will be reduced and the environment will benefit. To the extent that these installations apply CHP, the environmental benefit will be even greater. The simple comparisons in Figures 2-3 to 2-6 indicate that DG technologies can provide significant environmental benefits in addition to the economic and operational benefits that they offer to owners and operators. 


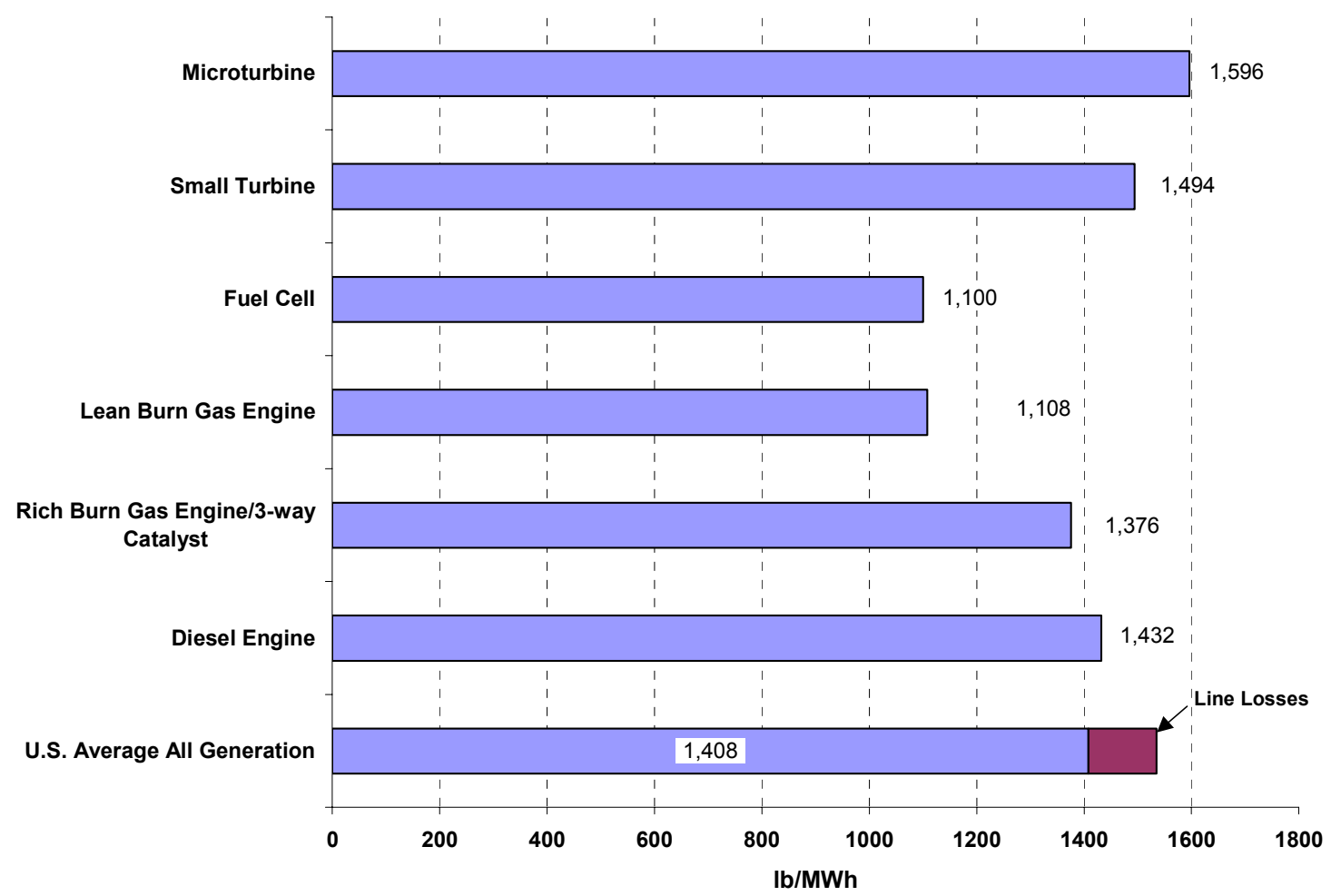

Figure 2-6

$\mathrm{CO}_{2}$ Emissions Comparison

\section{Analyzing Emission Displacement}

A quantitative assessment of the environmental impact of DG requires calculation of the central power emissions that are displaced or avoided when DG facilities operate. To a large degree, electricity demand is a zero sum game and the increased operation of one generator means less operation from some other generator. Calculating which generators are displaced by DG and the resulting emissions impact can be a complicated task that is location and time dependent. Some analysts initially assumed that DG would displace only new, very clean gas combined cycle plants and would therefore have small or negative environmental impacts. More recently, there has been increasing agreement that DG will displace a mix of generation that varies depending on location and time of day and year. Several analyses have been done or are underway to quantitatively evaluate the displaced emissions:

- The Center for Clean Air Policy did an analysis of on-site CHP in the northeast. ${ }^{1}$ The analysis used detailed dispatch modeling to assess the environmental impact of CHP projects in different parts of the northeast. The modeling showed that the CHP facility displaced a mix of generating assets ranging from baseload coal plants to new gas combined cycles, depending on the location and operating cycle.

- The New England Independent System Operator (NE-ISO) annually calculates the marginal emission rate for the system. This is an indication of the emissions that would be displaced by an incremental unit of non-grid generation or energy efficiency. The November 2001 analysis estimated the marginal $\mathrm{NO}_{\mathrm{x}}$ emission rate of the New England electric grid at approximately $2 \mathrm{lb} /$ megawatt hour (MWh), higher than many of the DG technologies. ${ }^{2}$

- The EPA is undertaking a nationwide analysis to develop marginal emission factors by region and time. The year is divided into 11 time periods and five geographic regions. The analysis should be complete in late $2002 .^{3}$

${ }^{1}$ Morris, Catherine, "Promoting Clean Power, Clean Air and Brownfield Redevelopment." Center for Clean Air Policy, January 2001.

${ }^{2}$ New England ISO, “1999 NEPOOL Marginal Emission Rate Analysis.” November 2001.

${ }^{3}$ Morgan, Rick, “Average Displaced Emissions Rate (ADER): Approach and Methodology.” U.S. EPA, June 2002. 


\section{5 $\mathrm{NO}_{\mathrm{x}}$ Control Technologies for DG}

As noted above, $\mathrm{NO}_{\mathrm{x}}$ emissions are the primary emission control issue for DG technologies and there are two primary approaches to this issue:

- Low-NO $\mathrm{NO}_{\mathrm{x}}$ combustion technologies (inherently low-emitting combustion and process design)

- Post-combustion $\mathrm{NO}_{\mathrm{x}}$ control

The primary focus of emission control for DG technologies has been inherently low emitting low $\mathrm{NO}_{\mathrm{x}}$ combustion technology. This is the preferred approach to emissions reduction for the small DG (less than 1MW). The cost of post-combustion $\mathrm{NO}_{\mathrm{x}}$ control technologies developed for large power plants does not scale linearly with size and can be prohibitively expensive for small DG. However post-combustion control technologies must be considered, especially for larger DG

\subsubsection{Low-NO Combustion Technologies}

Most DG technologies apply some form of low- $\mathrm{NO}_{\mathrm{x}}$ combustion. The formation of $\mathrm{NO}_{\mathrm{x}}$ is primarily linked to a high-temperature reaction between oxygen and nitrogen in the combustion air. Low- $\mathrm{NO}_{\mathrm{x}}$ combustion designs try to minimize this reaction by limiting the peak combustion temperature and by controlling the availability of oxygen at times when $\mathrm{NO}_{\mathrm{x}}$ could be formed. In many cases, extra combustion air is used to cool the flame. This is referred to as "lean" combustion because there is more combustion air than is needed to burn the available fuel. In reciprocating engines these techniques are referred to as "lean-burn combustion." Gas turbine versions of this approach include "dry low-NO $\mathrm{N}_{\mathrm{x}}$ " or "DLN" combustion and "lean pre-mix" combustion. These techniques typically include very sophisticated management of fuel and combustion air to maintain low emissions and good performance over a wide operating range.

Another, less developed low- $\mathrm{NO}_{\mathrm{x}}$ technology is "catalytic combustion." This approach uses a catalyst to flamelessly oxidize the fuel and release its heat at a temperature below the $\mathrm{NO}_{\mathrm{x}}$ formation temperature. Catalytic combustion has been demonstrated for combustion turbines and has achieved very low- $\mathrm{NO}_{\mathrm{x}}$ levels. The cost and durability have yet to be demonstrated, but some companies are starting to offer turbines using this technology.

Though highly sophisticated and complex in their design, low- $\mathrm{NO}_{\mathrm{x}}$ combustion systems are simpler and easier for users to operate and maintain than post-combustion technologies. This makes them well suited to DG applications in which the goal is to minimize user requirements.

\subsubsection{Post-Combustion $\mathrm{NO}_{x}$ Control Technologies}

There are several post-combustion technologies that can be applied to DG units to reduce $\mathrm{NO}_{\mathrm{x}}$. Most of these were developed for larger combustion systems and have significant operational or cost drawbacks in DG applications. Nevertheless, they are often considered favorably by regulators and need to be understood in evaluating regulation of DG projects. These $\mathrm{NO}_{\mathrm{x}}$ control technologies include the 3-way catalyst (for rich-burn gas engines) and selective catalytic reduction (SCR) and $\mathrm{SCONO}_{\mathrm{x}}{ }^{\mathrm{TM}}$ (for lean-burn gas engines, diesel engines, and combustion turbines).

The 3-way catalyst is the same technology used to control emissions from automobiles. It gets its name because it reduces emissions of $\mathrm{NO}_{\mathrm{x}}, \mathrm{CO}$ and unburned hydrocarbons (also called volatile organic compounds or VOC). It is a passive technology that is efficient and relatively simple. However, it can only be 
used when there is no excess oxygen in the exhaust stream. For this reason, it cannot be used for lean-burn gas engines, diesel engines, and combustion turbine systems, which operate at fuel/air ratios that result in high excess exhaust oxygen. Some natural gas engines ("rich-burn" engines) can apply the 3way catalyst but are less efficient than the more standard lean-burn natural gas engines. The capital cost of the 3-way catalyst is about $\$ 55 / \mathrm{kW}$.

SCR is the most common add-on $\mathrm{NO}_{\mathrm{x}}$ control system in use for technologies that cannot use a 3-way catalyst due to excess air in their exhaust (lean-burn engines, diesel engines, and combustion turbines). SCR works by injecting ammonia into the exhaust gas in the presence of a catalyst bed. The ammonia reacts with the $\mathrm{NO}_{\mathrm{x}}$ in the exhaust gas to form nitrogen and water. SCR has been shown to be very effective in reducing $\mathrm{NO}_{\mathrm{x}}$ emissions, typically by up to $90 \%$. Although SCR is applicable to most combustion technologies, it is effective only over a limited temperature range and does not reduce $\mathrm{NO}_{\mathrm{x}}$ emissions as effectively at the high temperatures typical of simple cycle peaking turbines ${ }^{19}$.

Another problem is that some ammonia is not consumed and is emitted in the flue gas; this is known as ammonia slip. The ammonia injection rate must be carefully controlled to maintain an ammonia-to- $\mathrm{NO}_{\mathrm{x}}$ ratio that effectively reduces $\mathrm{NO}_{\mathrm{x}}$ and avoids excessive ammonia slip. Also, ammonia is classified as a hazardous substance that requires special handling and safety precautions that may only be acceptable in industrial settings. This might preclude SCR use for DG applications in commercial, institutional, or residential settings. In some cases urea is used instead of ammonia. Urea is less hazardous but still

\footnotetext{
${ }^{19}$ New high-temperature SCR systems are being developed, however they are more expensive and there is less experience with them.
}

noxious and probably not acceptable in some applications. Also, SCR has a high capital cost that is relatively insensitive to the size of the system, making the per-unit cost higher for small applications than for large central power systems. Instead of $\$ 50 / \mathrm{kW}$ for large gas-fired generators, SCR for small generators can add $\$ 150$ to $\$ 200 / \mathrm{kW}$ - nearly $20 \%$ to the capital cost of a small DG system.

The $\mathrm{SCONO}_{\mathrm{X}}^{\mathrm{TM}}$ system is a relatively new $\mathrm{NO}_{\mathrm{x}}$ control technology that eliminates ammonia issues. $\mathrm{SCONO}_{\mathrm{X}}{ }^{\mathrm{TM}}$ absorbs $\mathrm{NO}_{\mathrm{x}}$ onto a surface that is periodically regenerated with a hydrogen-rich gas. During regeneration, the $\mathrm{NO}_{\mathrm{x}}$ is converted to nitrogen and water. $\mathrm{SCONO}_{\mathrm{X}}{ }^{\mathrm{TM}}$ has been shown to achieve very low- $\mathrm{NO}_{\mathrm{x}}$ levels in a few installations. $\mathrm{SCONO}_{\mathrm{X}}{ }^{\mathrm{TM}}$ does not use ammonia but is mechanically more complicated and even more expensive than SCR.

Cost of Add-on $\mathrm{NO}_{x}$ Controls-Table 2-2 summarizes the costs of add-on $\mathrm{NO}_{\mathrm{x}}$ control for some typical DG systems. It shows:

- The cost of the basic generating technology

- The baseline emissions

- The cost of the $\mathrm{NO}_{\mathrm{x}}$ control technology (capital and annualized)

- The $\mathrm{NO}_{\mathrm{x}}$ control capital cost as a percentage of the DG technology cost

- The cost of $\mathrm{NO}_{\mathrm{x}}$ reductions in \$/ton reduced.

The table shows that a $5 \mathrm{MW}$ turbine at a 15 parts per million (ppm) $\mathrm{NO}_{\mathrm{x}}$ emission baseline has potential emissions of about 13.5 tons per year (tpy). Adding SCR adds about $17 \%$ of the capital cost of the turbine generating system. The annualized cost of the SCR (capital and operating) is about $\$ 352,000$ per year. If the system reduces $\mathrm{NO}_{\mathrm{x}}$ by $88 \%$ 
Table 2-2

Cost of Add-On $\mathrm{NO}_{x}$ Controls

\begin{tabular}{|c|c|c|c|c|c|}
\hline & $\begin{array}{l}\text { Gas Turbine } \\
\text { with SCR }\end{array}$ & $\begin{array}{c}\text { Gas Turbine } \\
\text { with } \\
\text { SCONO }_{x}\end{array}$ & $\begin{array}{l}\text { Large Lean- } \\
\text { burn Gas } \\
\text { Engine with } \\
\text { SCR }\end{array}$ & $\begin{array}{l}\text { Small Lean- } \\
\text { burn Gas } \\
\text { Engine with } \\
\text { SCR }\end{array}$ & $\begin{array}{c}\text { Rich-burn } \\
\text { Gas Engine } \\
\text { with 3-Way } \\
\text { Catalyst }\end{array}$ \\
\hline Generator Size $(\mathrm{kW})$ & 5,200 & 5,200 & 2,000 & 500 & 500 \\
\hline Generator Cost $(\$ / \mathrm{kW})$ & $\$ 850$ & $\$ 850$ & $\$ 690$ & $\$ 690$ & $\$ 725$ \\
\hline Total Cost (\$) & $\$ 5,746,000$ & $\$ 5,746,000$ & $\$ 1,794,000$ & $\$ 448,500$ & $\$ 471,250$ \\
\hline $\mathrm{NO}_{\mathrm{x}}$ Emissions & $15 \mathrm{ppm}$ & $15 \mathrm{ppm}$ & $0.7 \mathrm{~g} / \mathrm{bhp}$ & $1.5 \mathrm{~g} / \mathrm{bhp}$ & $14 \mathrm{~g} / \mathrm{bhp}$ \\
\hline (lb/MWh) & 0.59 & 0.59 & 2.18 & 4.67 & 43.5 \\
\hline (tons/year) & 13.5 & 13.5 & 19.1 & 10.2 & 95.4 \\
\hline Control Technology & SCR & SCONOx & SCR & SCR & TWC \\
\hline Cost $(\$ / k W)$ & $\$ 120$ & $\$ 339$ & $\$ 125$ & $\$ 210$ & $\$ 55$ \\
\hline Total Cost (\$) & $\$ 998,400$ & $\$ 1,762,800$ & $\$ 250,000$ & $\$ 105,000$ & $\$ 30,888$ \\
\hline$\%$ of generator cost & $17 \%$ & $31 \%$ & $14 \%$ & $23 \%$ & $7 \%$ \\
\hline Annual Control Cost (\$) & $\$ 351,558$ & $\$ 495,895$ & $\$ 157,518$ & $\$ 121,984$ & $\$ 14,969$ \\
\hline$\%$ reduction $(\%)$ & $88 \%$ & $92 \%$ & $88 \%$ & $88 \%$ & $99 \%$ \\
\hline Reduction (tpy) & 11.9 & 12.4 & 16.8 & 9.0 & 94.4 \\
\hline Control Cost (\$/ton) & $\$ 29,553$ & $\$ 39,874$ & $\$ 9,386$ & $\$ 13,568$ & $\$ 159$ \\
\hline
\end{tabular}

(12 tons), the cost of control is almost $\$ 30,000 /$ ton reduced - higher than even the highest regulatory cost thresholds, which typically range from a few thousand dollarsper-ton up to $\$ 12,000$ to $\$ 13,000 /$ ton (see Chapter 3).

Applying $\mathrm{SCONO}_{\mathrm{x}}$ to the same turbine yields an even higher cost. The capital cost is higher; $31 \%$ of the cost of the turbine and the annualized cost is almost $\$ 496,000$ per year. Although the $\mathrm{NO}_{\mathrm{x}}$ reduction is slightly greater -over 12 tpy, the control cost is almost $\$ 40,000 /$ ton of $\mathrm{NO}_{\mathrm{x}}$ reduced.

The cost of SCR for the $2 \mathrm{MW}$ and $500 \mathrm{~kW}$ lean-burn gas engines ranges from about $14 \%$ to $23 \%$ of the generator cost. This cost is much higher for the small engine because the SCR cost does not scale linearly with size. However, because the baseline emissions of the gas engines are 4 to 8 times higher than those of the gas turbines, the cost of reduction is lower$\$ 9,400 /$ ton for the $2 \mathrm{MW}$ engine and $\$ 13,600 /$ ton for the $500 \mathrm{~kW}$ engine. These levels are still at the high end of the regulatory cost thresholds, however.

The three-way catalyst applied to the richburn gas engine has a much lower capital cost, about $\$ 55 / \mathrm{kW}$ and very low operating costs. The rich-burn engine also has a higher uncontrolled emissions baseline, 95.4 tons per year and a $99 \%$ removal efficiency. The result is a very low control cost of $\$ 159 /$ ton reduced.

These examples illustrate that the small size of DG technologies results in high per-unit costs of control technology. In addition, DG technologies that have low baseline emissions have even higher emission control cost effectiveness levels (\$/ton), typically higher than the maximum regulatory cost thresholds applied to larger technologies.

Figure 2-7 compares these control costs with the cost of control for SCR on a large combined cycle gas turbine. Based on data from the EPA BACT/LAER clearinghouse, the control cost for a large combined cycle is 
around $\$ 3,000 /$ ton. This is much lower than the cost of SCR or $\mathrm{SCONO}_{x}$ for the DG technologies, largely due to the diseconomies of scale in applying these post-combustion control technologies to small generators.

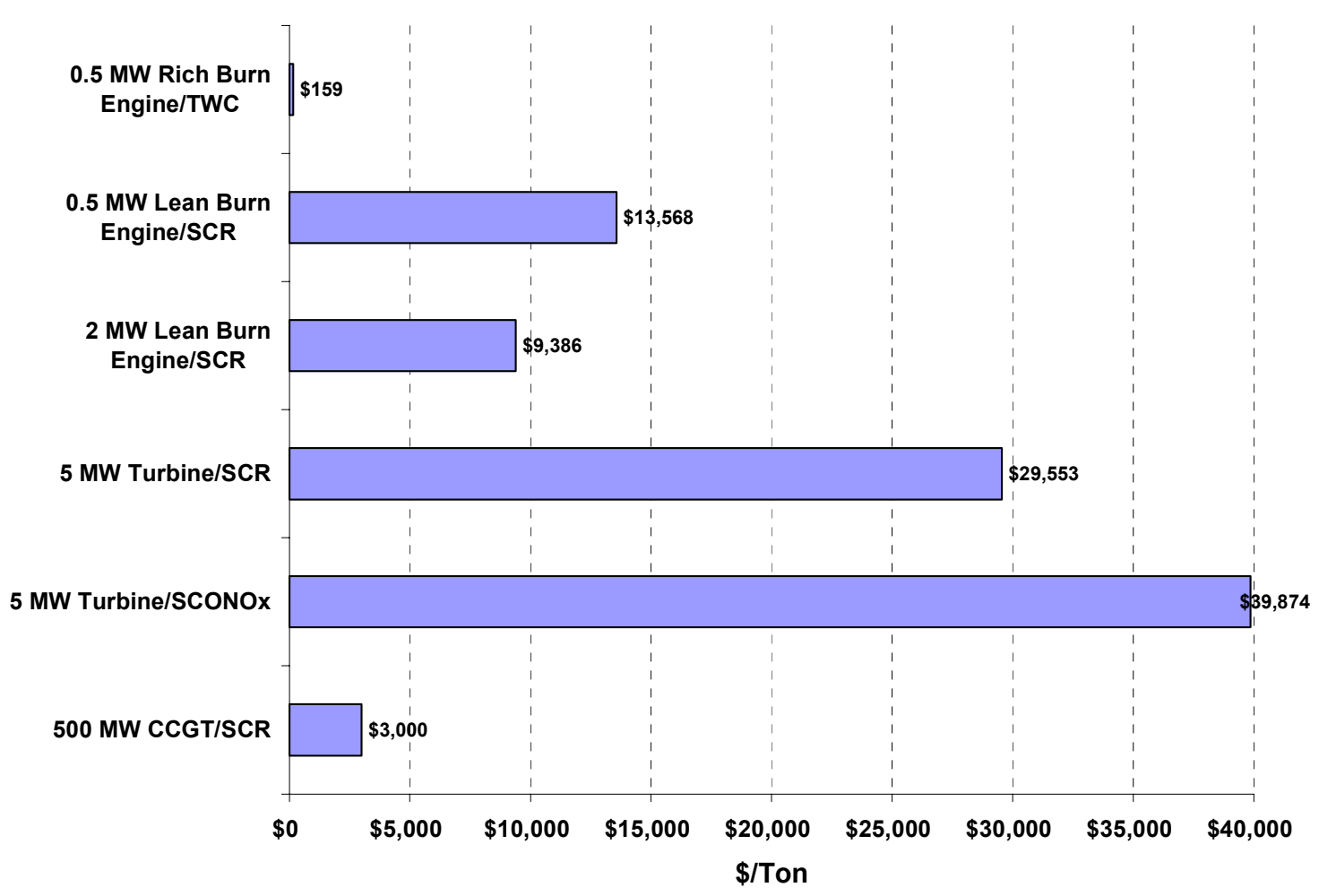

Figure 2-7

Cost-Effectiveness of Post-Combustion $\mathrm{NO}_{x}$ Controls 


\section{Chapter 3. Air Quality Regulation of Power Generation in the United States}

\subsection{Federal Laws and Regulations Applicable to Power Generation}

To understand the permitting issues associated with DG, it is necessary to understand the regulatory framework that applies to power generators of all sizes. Many of the air regulations were designed for large emissions sources and focus on the use of add-on emission controls. This fact explains why some of these regulations do not recognize the environmental benefits or other relevant characteristics of very small, clean DG technologies.

Clean Air Act of 1970-The federal Clean Air Act of 1970 and its amendments, especially the 1990 Amendments, are the basis of most air pollution policy and regulation in the United States. ${ }^{20}$ The Clean Air Act is the comprehensive federal law that regulates air emissions from area, stationary, and mobile sources.

One of the most important components of this law is the requirement for the Environmental Protection Agency (EPA) to establish

National Ambient Air Quality Standards (NAAQS) to protect public health and the environment. The NAAQS, as promulgated by the EPA from time to time, form the foundation of the U.S. air quality program. ${ }^{21}$

\footnotetext{
${ }^{20}$ Clean Air Act, 42 U.S.C. s/s 7401 et seq. (1970). The Act was amended in 1977 primarily to set new goals (dates) for achieving attainment of NAAQS since many areas of the country had failed to meet the deadlines. The 1990 amendments to the Clean Air Act in large part were intended to meet unaddressed or insufficiently addressed problems such as acid rain, ground-level ozone, stratospheric ozone depletion, and air toxics.

${ }^{21}$ The EPA Office of Air Quality Planning and Standards (OAQPS) sets the National Ambient Air Quality Standards
}

The NAAQS set standards for 6 pollutants, called "criteria pollutants." The criteria pollutants of greatest relevance to DG are $\mathrm{NO}_{\mathrm{x}}$ (as a precursor to ground level ozone or smog), $\mathrm{CO}, \mathrm{SO}_{2}$, and PM. As discussed in Chapter 2, the primary and often only criteria pollutant that significantly affects most DG projects is $\mathrm{NO}_{\mathrm{x}}$.

The NAAQS goals of health-based standards for the quality of ambient air are designed to ensure that the air everywhere in the United States is fit to breathe. Locations throughout the United States are classified as either "in attainment" (meeting the ambient air quality limits) of the NAAQS or "nonattainment" for a given pollutant. Figure 3-1 shows the nonattainment areas for ozone, the driver for $\mathrm{NO}_{\mathrm{x}}$ controls. In attainment areas, which comprise most of the country, the focus is on maintaining good air quality through the program called Prevention of Significant Deterioration (PSD). In nonattainment areas, the goal is restoring air quality. Although only a small geographic portion of the country is currently classified as nonattainment, this portion includes a substantial portion of the population and market for DG.

The NAAQS are also becoming more stringent over time. The EPA promulgated new standards for both ozone and particulates in July of 1997. These new standards will expand the areas designated as nonattainment and, therefore, needing to meet more stringent requirements. For example, most areas of the eastern United States will probably become nonattainment for ozone by 2010 under the new standard.

for the six principal "criteria" pollutants, which may be found at http://www.epa.gov/airs/criteria.html. 


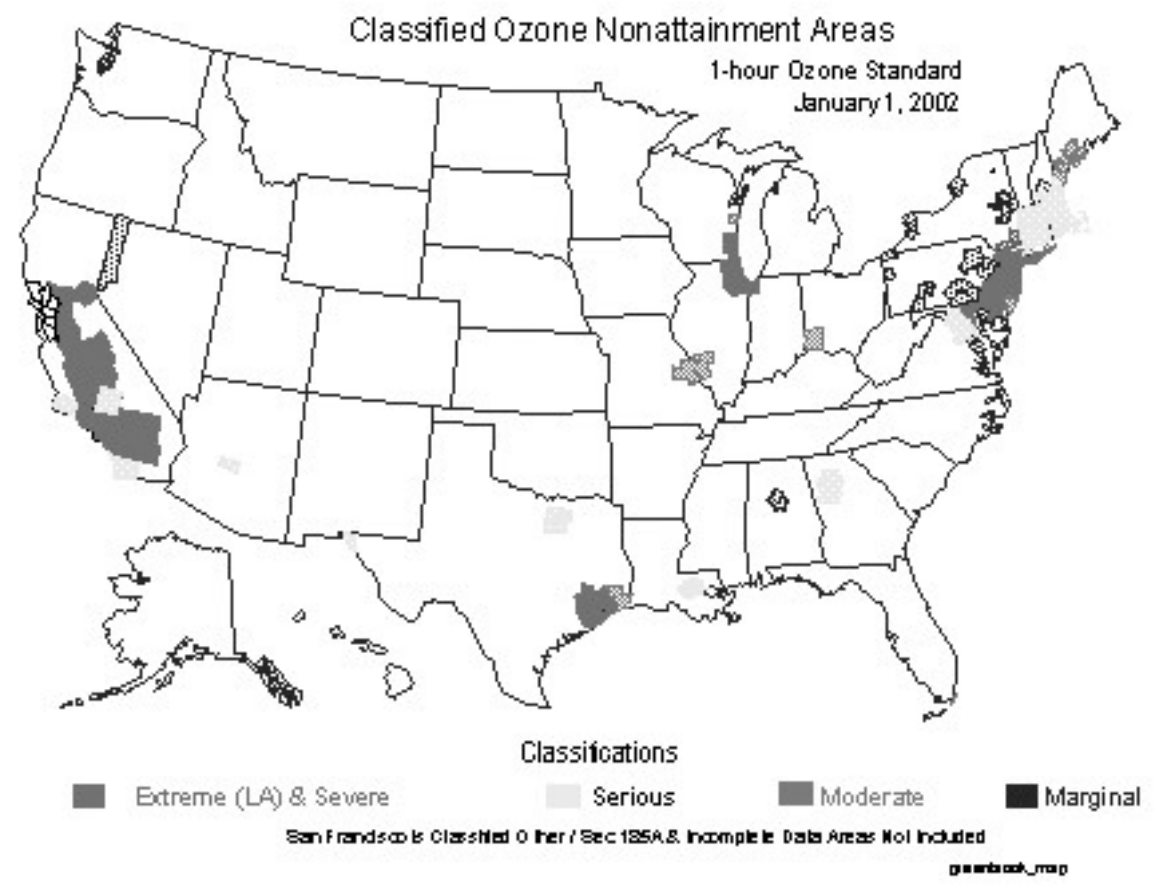

Figure 3-1

Ozone Nonattainment Areas

New Source Review-The NAAQS represent standards $^{22}$ for the ambient air quality - what directly affects health - rather than for specific sources that in turn determine ambient air quality. However, the NAAQS program also sets requirements for a variety of programs to ensure that the standards are met. These programs are established and overseen by the federal government but implemented by individual states. The interplay between national standards and state implementation has given rise to a variety of different regulations, sometimes overlapping and even conflicting, which may apply to stationary sources including DG.

To meet the NAAQS goals, the Clean Air Act requires pre-construction environmental permitting of new stationary facilities in all

\footnotetext{
22 The Clean Air Act established two types of national air quality standards. Primary standards set limits to protect public health, including the health of "sensitive" populations such as asthmatics, children, and the elderly. Secondary standards set limits to protect public welfare, including protection against decreased visibility, damage to animals, crops, vegetation, and buildings.
}

parts of the United States that emit criteria pollutants. The new source permitting program, generically known as new source review (NSR), ${ }^{23}$ sets emission control requirements for the criteria pollutants for new and modified facilities. Although the permitting process is established and regulated under federal law, it is administered by the states, leading to a high degree of variability in its implementation.

Where environmental permitting problems exist for new DG projects, NSR is the most likely concern. In particular, the problem is likely to be "minor source review" in a nonattainment area - the areas in which all sources, including small DG projects, receive the most scrutiny.

\footnotetext{
${ }^{23}$ NSR is generally used to refer to both the Title I (Part C) prevention of significant deterioration (PSD) program and the Title I (Part D) nonattainment new source review (nonattainment NSR) program. Regulations implementing these programs are found in 40 CFR Parts 51 and 52.
} 
Applicability of New Source Review-The manner in which the NSR permitting process applies to a proposed project is determined by the "potential emissions" of the affected source. ${ }^{24}$ Potential emissions means the total annual emissions if the source were to run at full capacity for an entire year. New or modified sources that exceed certain potential emissions thresholds are called "major sources" and are subject to the federal NSR program. If emissions are below the major source threshold, sources are subject to "minor source review." Finally, there is usually an emission or size threshold below which sources are exempt from environmental permitting. This regulatory framework applies to all sources equally, whether they are central station power plants, other large sources, or small projects such as distributed generators.

Whether a proposed project's potential emissions are high enough to trigger NSR depends on its location. The major source threshold varies according to the local air quality attainment status. As shown in Table 3-1, the threshold for major source review of a new source in a nonattainment area ranges from 100 tons per year (tpy) down to 10 tpy depending on local air quality. The major source threshold for $\mathrm{NO}_{\mathrm{x}}$ for PSD review of a new source in ozone attainment areas is a net emissions increase of either 100 or 250 tpy depending on the type of source. Modification of a source can also trigger NSR/PSD, if it results in an increase in potential emissions.

Table 3-1

Major Source Thresholds for $\mathbf{N O}_{\mathbf{x}}$

\begin{tabular}{lcc}
\hline Nonattainment Classification & $\begin{array}{c}\text { Major Source Threshold } \\
\text { for New Sources }\end{array}$ & $\begin{array}{c}\text { Major Source Threshold for } \\
\text { Modified Sources }\end{array}$ \\
\hline Attainment Area & $100 / 250$ tpy & 40 tpy \\
Ozone Nonattainment Areas: & 100 tpy & 40 tpy \\
Ozone Transport Region & 100 tpy & 40 tpy \\
Moderate & 50 tpy & 25 tpy \\
Serious & 25 tpy & 25 tpy \\
Severe & 10 tpy & 0 tpy \\
Extreme &
\end{tabular}

Table 3-1 shows that the trigger levels for modifications are lower than for new sources. The threshold for modifications in attainment areas is a net emissions increase of only 40 tpy. The major source threshold for modifications in nonattainment areas ranges from 40 tpy down to zero tpy in the Los Angeles extreme nonattainment area. This lower threshold for modifications is quite significant because it is common to add a DG unit to an existing facility.

\footnotetext{
${ }^{24}$ The NSR program applicability threshold applies to the entire facility, not individual units. An individual DG unit might not trigger NSR but could be part of a larger project that triggers NSR.
}

To put these major source thresholds in context, Table 3-2 lists the potential $\mathrm{NO}_{\mathrm{x}}$ emissions of some representative-size DG technologies. Comparing Tables 3-1 and 3-2 shows that, except for diesel generators in serous ozone nonattainment areas, small DG projects are unlikely to trigger major source review, even for modifications. 


\section{Table 3-2}

\begin{tabular}{lcc} 
Potential $\mathbf{N O}_{\mathbf{x}}$ Emissions of DG Technologies \\
\hline Technology & $\begin{array}{c}\text { Size } \\
(\mathrm{kW})\end{array}$ & $\begin{array}{c}\text { Potential } \mathrm{NO}_{\mathbf{x}} \\
\text { Emissions } \\
\text { (tpy) }\end{array}$ \\
\hline Gas Microturbine & 27 & 0.05 \\
Gas Engine & 500 & 8 \\
& 2,000 & 19 \\
Gas Turbine & 4,600 & 23 \\
& 10,000 & 28 \\
Diesel Engine & 44,000 & 104 \\
& 500 & 48 \\
& 1,500 & 140 \\
\hline
\end{tabular}

\subsubsection{Federal New Source Permits in Attainment Areas}

Best Available Control Technology (BACT) If a new or modified source in an attainment area triggers major new source review under the regulations for PSD, then the owner must identify the appropriate level of emission controls. In attainment areas, the standard is Best Available Control Technology (BACT).

BACT means the control technology that achieves the greatest emission reduction within a preset cost-per-ton-of-reduction criterion that varies by state. The operator must identify and evaluate all of the available control technologies for each unit and select the best one that meets this standard in order to receive a construction permit. Because emission control technologies and their costs change over time, BACT is a moving target that becomes more stringent over time and must be evaluated and negotiated on a case-by-case basis. ${ }^{25}$

\footnotetext{
${ }^{25}$ As set forth in a draft EPA New Source Review Workshop Manual, BACT must be performed in a case-by-case, top-down manner. During each BACT analysis, which is done on a caseby-case basis, the reviewing authority evaluates the energy,
}

Case-By-Case Determination of BACT Requires Negotiation-Cost effectiveness is the key economic criterion considered in the BACT analysis. Cost effectiveness is defined for these purposes as the control cost-per-ton of pollutant emissions reduced. The criterion in the cost effectiveness analysis is the cost of control and not the economic situation of the individual source. The key issue is whether the cost of control exceeds the predetermined cost -per-ton BACT threshold, which varies with the permitting location. The BACT cost threshold ranges from a few thousand dollars-per-ton of $\mathrm{NO}_{\mathrm{x}}$ reduced to $\$ 10,000$ to $\$ 15,000$-per-ton in areas with poorer air

environmental, economic, and other characteristics of the control technology. "In brief, the top-down process provides that all available control technologies be ranked in descending order of control effectiveness. The PSD applicant first examines the most stringent-or "top"alternative. That alternative is established as BACT unless the applicant demonstrates, and the permitting authority in its informed judgment agrees, that technical considerations, or energy, environmental, or economic impacts justify a conclusion that the most stringent technology is not "achievable" in that case. If the most stringent technology is eliminated in this fashion, then the next most stringent alternative is considered, and so on." See http://www.epa.gov/ttn/nsr/gen/wkshpman.pdf. 
quality. ${ }^{26}$ This process of determining the appropriate level of control technology and the associated negotiation with regulators is the focus of many of the regulatory disagreements in the permitting of major sources. Although these new source permits are driven by federal requirements and developed under federal oversight, the states or local air agencies negotiate, issue, and administer the permits and permitting process.

\subsubsection{Federal New Source Permits in Nonattainment Areas.}

In nonattainment areas, the goal is restoring air quality through nonattainment NSR. As noted above, the major source thresholds are lower in nonattainment areas. Sources that trigger NSR in nonattainment areas also must meet a more stringent level of control called Lowest Achievable Emissions Reduction (LAER). LAER is defined as the most effective control technology demonstrated in practice, without regard to cost. Like BACT, LAER is inherently a moving target that becomes more stringent over time and must also be evaluated and negotiated on a case-by-case basis.

\subsubsection{State Emission Permits for Minor New Source Review}

While major sources trigger extensive permitting and emission control requirements, sources that do not trigger federal NSR, including most DG projects, may still face state minor source permitting requirements. Minor source requirements are set by the state and are much more variable than federal NSR. These state requirements can range from no control requirement to LAER levels of control. Many set fixed emission limits while some are caseby-case determinations similar to BACT or LAER.

\footnotetext{
${ }^{26}$ California applies a state "BACT" criterion with a higher cost threshold; however, most of California is nonattainment for ozone and the state BACT is commonly recognized as equal to LAER in other parts of the country.
}

Frequently, stringent standards will "migrate" from one area to another once a precedent has been set. For example, a very stringent $\mathrm{NO}_{\mathrm{x}}$ requirement for gas engines ${ }^{27}$ in the extreme nonattainment area of Los Angeles is now being taken as the basis for regulations in other areas of the country. Control requirements can also "migrate" from one size class to another. In some cases, the technology requirements developed in the BACT analysis for large sources are applied as a fixed limit for small sources. ${ }^{28}$ These practices apply emissions limits out of their appropriate context and arbitrarily impose limits or costs that would not be applied if the regulatory standards or analysis applied to larger generators were followed.

\subsection{State Distributed Generation Regulations}

As discussed above, individual states are responsible for regulating minor air emission sources. California and Texas have recently become the first states to enact air emission standards specifically for DG.

\subsubsection{California}

In 2000, California passed Senate Bill (SB) 1298 requiring the California Air Resource Board (CARB) to set new standards and provide guidance for permitting new DG projects. SB 1298 calls for the CARB to establish an emission certification program by 2003 for small electric generation projects that are currently exempt from air emission permitting. The size of the affected generators varies according to the local rules in each of the 35 California air quality districts, but the certification rule primarily

\footnotetext{
${ }^{27}$ South Coast Air Quality Management District limit of $0.15 \mathrm{~g} \mathrm{NO}_{\mathrm{x}} / \mathrm{bhp}-\mathrm{hr}$

${ }^{28}$ For example, if a state finds that BACT for large combined cycle turbines is $3 \mathrm{ppm}$ using SCR, it may set that as a fixed limit for small turbine projects.
} 
affects generators less than one MW and in many cases only those less than $100 \mathrm{~kW}$.

The program starts with the standards in Table 3-3, based on best current performance for small DG technologies, then moves to the more stringent standards in Table 3-4 based on best performance of central station generation. SB 1298 also requires CARB to develop a BACT guidance document for DG projects less than $50 \mathrm{MW}$ but large enough to require local district permits. (BACT in California is equivalent to LAER in other states.

The initial phase standards in Table 3-3 will be effective from January 1, 2003 to December 31, 2006. The first column applies to electricity- only technologies. The second column applies if a DG unit is integrated with CHP. If a DG unit is integrated with wind or solar electric generation technology, the third column applies. The second phase (Table 34) will take effect January 1, 2007.

No fossil-fueled DG technologies other than fuel cells are currently able to meet the $\mathrm{NO}_{\mathrm{x}}$ standard for 2007. A comparison with Figure 2-5 shows that this $\mathrm{NO}_{\mathrm{x}}$ level is almost 10 times lower than the best existing combustion DG technologies. There are currently no foreseeable technologies that will allow conventional DG technologies (non-CHP combustion technologies) to reach this level.

Table 3-3

Proposed California 2003 DG Certification Standards

\begin{tabular}{llll}
\hline Pollutant & $\begin{array}{l}\text { DG } \\
(\mathrm{lb} / \mathrm{MWh})\end{array}$ & $\begin{array}{c}\text { W/CHP } \\
(\mathrm{lb} / \mathrm{MWh})\end{array}$ & $\begin{array}{c}\text { W/Renewable } \\
(\mathrm{lb} / \mathrm{MWh})\end{array}$ \\
\hline Oxides of Nitrogen & 0.5 & 0.7 & 1.0 \\
Carbon Monoxide & 6.0 & 6.0 & 6.0 \\
Volatile Organic Compounds & 1.0 & 1.0 & 1.0 \\
\hline
\end{tabular}

Table 3-4 Proposed California 2007 DG Certification Standards

\begin{tabular}{lc}
\hline Pollutant & $\mathrm{lb} / \mathrm{MWh}$ \\
\hline Oxides of Nitrogen & 0.07 \\
Carbon Monoxide & 0.08 \\
Volatile Organic Compounds & 0.02 \\
\hline
\end{tabular}




\subsubsection{Texas}

On May 23, 2001, the Texas Natural Resource Conservation Commission (TNRCC) approved new air emissions standards ${ }^{29}$ for small electric generating units. The standards are divided between east and west Texas. The rule also addresses system size and capacity factors.

Parts of East Texas have the worst air quality in the nation and therefore already have very stringent limits for emissions from all sources. For units $10 \mathrm{MW}$ or less installed in east Texas prior to 2005 and operating more than 300 hours per year, the limit is $0.47 \mathrm{lb}$ $\mathrm{NO}_{\mathrm{x}} / \mathrm{MWh}$. This is slightly lower than the 2003 CARB certification standard and can currently be met only by very low-emitting gas engines, microturbines, and fuel cells. The 2005 limit of $0.14 \mathrm{lb} / \mathrm{MWh}$ can only be met today by fuel cells. A market study is being performed to see whether the 2005 standard is appropriate. For units operating less than 300 hours per year, the limit is 1.65 $\mathrm{lb} / \mathrm{MWh}$, declining to $0.47 \mathrm{lb} / \mathrm{MWh}$ in 2005 .

Table 3-5

Texas $\mathrm{NO}_{\mathrm{x}}$ General Permit Limits for Units less than $10 \mathrm{MW}$

\begin{tabular}{lcc}
\hline & Installed Prior to 2005 & Installed In 2005 or Later \\
\hline East Texas & $0.47 \mathrm{lb} / \mathrm{MWh}$ & \\
Operates more that $300 \mathrm{hrs} / \mathrm{yr}$ & $1.65 \mathrm{lb} / \mathrm{MWh}$ & $0.14 \mathrm{lb} / \mathrm{MWh}$ \\
Operates less than $300 \mathrm{hrs} / \mathrm{yr}$ & & $0.47 \mathrm{lb} / \mathrm{MWh}$ \\
& & \\
& & \\
West Texas & $211 \mathrm{lb} / \mathrm{MWh}$ & $3.11 \mathrm{lb} / \mathrm{MWh}$ \\
Operates more than $300 \mathrm{hrs} / \mathrm{yr}$ & $21 \mathrm{lb} / \mathrm{MWh}$ & $2 \mathrm{MWh}$ \\
Operates less than $300 \mathrm{hrs} / \mathrm{yr}$ & & \\
\hline
\end{tabular}

The west Texas requirements for units $10 \mathrm{MW}$ or less are not as stringent. The limit of 21 $\mathrm{lb} / \mathrm{MWh}$ for units operating 300 hours per year or less can be met by diesel engines and most other DG technologies. The $3.11 \mathrm{lb} / \mathrm{MWh}$ limit for higher-capacity-factor units can be met by combustion turbine technologies and many lean-burn gas engines.

The Texas rule allows a DG project that employs CHP to take a credit based upon the amount of heat recovered. The credit is 1 MWh for each 3.4 MMBtu of heat recovered. The thermal output must be at least $20 \%$ of the total output.

The Texas and California rules are examples of new approaches to DG regulation that offer simpler treatment but set limits that are not achievable by today's conventional DG technology.

${ }^{29} \mathrm{http} / /$ www.tnrcc.state.tx.us/permitting/airperm/nsr permits/fi $\underline{\text { les/segu final.pdf }}$ 


\section{Chapter 4. Findings}

\subsection{Introduction}

The analysis of specific air quality permitting experiences of the $51 \mathrm{DG}$ projects undertaken for this study revealed a wide range of fact patterns - some of which indicated no impediments at all. In the many parts of the United States that are in attainment for most pollutants, the emission levels of most DG projects are too low to trigger detailed scrutiny. In many regions, these small projects require little or no effort to permit and are subject to only insignificant emission limits and control requirements. $^{30}$

However, initial review of the remaining cases confirmed a number of findings that relate specifically to DG projects because of their small size, their location at the point of use, or other characteristics specific to DG. These aspects of environmental regulatory treatment of DG projects are of serious concern because they either:

- Do not appropriately credit DG projects for their environmental benefits; or

- Do not properly account for the ways in which small-scale DG projects are different from large-scale generating projects. ${ }^{31}$

\footnotetext{
${ }^{30}$ Even in these regions, however, there were cases in which project developers experienced delays in negotiating even these limited requirements. In some cases, the problem was attributed to the regulators. In other cases, it was the result of inexperience or lack of knowledge on the part of the developer. There were also the complaints over the complexity and cost of new source permitting that arise whenever the topic is discussed. Due to the case-by-case nature of NSR, there are often disagreements over the outcome and dissatisfactions over the cost. These complaints however are not specific to DG projects and raise broader regulatory issues than are to be addressed here.

${ }^{31}$ As noted in Chapter 2, the current regulation framework does not account for the environmental benefit of avoiding transmission and distribution losses or the potential for doubling to tripling generation efficiency.
}

These cases tended to arise in nonattainment areas because those are the areas in which small projects are most likely to receive significant scrutiny. The specific issues identified and confirmed in the case studies include:

- No emissions credit for CHP. That is, the basic permitting process does not take into account the fact that the project is providing more than kilowatt-hours through electricity generation. Thus, the basic permitting approach ignores the benefits of one of the most important tools available for raising the overall efficiency of electricity generation, namely using the available thermal output.

- No credit for avoided or displaced emissions.

- The inherent incongruity between a complex, case-by-case permitting process designed for "large" generators and its application to small, standardized DG technologies relying on "mass production" and ease of installation for their economic viability.

- No consideration of very high unit costs of stringent emission limits for small, clean generators. The control costs for add-on control technologies are relatively insensitive to size and their application to small projects can result in unit control costs $(\$ / \mathrm{kW}$ or $\$ /$ ton $)$ much greater than those required for large projects.

- No credit for "pollution prevention" incorporated into the design of a DG technology in determination of control requirements. Cases were identified where regulators in some jurisdictions, intent on requiring additional pollution 
control equipment, apply the requirement for additional control equipment even if the generation technology already included pollution prevention elements that result in low emissions.

Although some of these issues are currently reported in only a few parts of the country, there is reason to be concerned that this treatment will spread. As new, more stringent ambient air quality standards for ground-level ozone and PM are implemented, more of the United States will be in nonattainment areas in which small projects receive more scrutiny. In this case, the permitting principles and structures established for DG projects in nonattainment areas today can be expected to be applied over a wider region in the future. The regulatory treatment of DG projects in nonattainment areas today will thus likely shape future treatment and the future of the DG industry.

Each of the regulatory issues identified for policy action is discussed below. One or more illustrative case example is provided for each of the issues.

\subsection{No Emissions Credit for CHP}

Because CHP is significantly more efficient than conventional separate generation of electric and thermal energy, it uses significantly less fuel and creates significantly lower emissions for the same productive outputs. Further, new CHP facilities often replace older, higher-emitting units. This additional environmental benefit is not recognized in the traditional permitting process.

From a permitting perspective, the essential problem is that CHP systems substitute a single on-site unit for two or more separate emitting units, one of which (the utility's power plant) is off-site and thus not taken into account in the traditional permitting process. Since the avoided off-site emissions are not considered in permitting the CHP facility, the CHP project will often appear to show an increase in emissions even though its total emissions are significantly lower than the total alternatives.

Alternatively, the project may be permitted based on requirements for electric generation without considering the avoided emissions from thermal generation. Even when a CHP facility has lower emissions than the "total" project that it is replacing, conventional environmental permitting does not recognize its environmental benefits. Because the CHP system is cleaner than the total pre-existing system, the net emission result is negative. This makes the electricity from this CHP facility cleaner overall than the cleanest new central station plant. Most states, however, do not provide any credit for the environmental benefits of CHP. ${ }^{32}$

None of the 14 CHP projects identified and evaluated for this study received credit for CHP benefits. This structural omission in conventional environmental permitting thus unnecessarily complicates and discourages the permitting of environmentally beneficial CHP projects. There are solutions available, however, and credit for CHP has recently been included in the California and Texas DG regulations discussed in Chapter 3.

\footnotetext{
${ }^{32}$ Another permitting problem related to CHP is the "source separation" issue. This occurs when regulators require a separately owned CHP facility to be regulated by the same air permit as the steam host facility. This creates a variety of commercial and operational conflicts that can make the third party CHP project impossible. This problem only applies to third party CHP projects, often larger than the ones discussed here. No specific examples of this issue were identified during the research for this study, however it is a significant problem for larger, third party CHP projects.
} 


\section{Example:}

Fact Summary

Issue: Credit for $\mathrm{CHP}$

Location: Nonattainment Area

Size: Minor Source

Technology: Combustion Turbine

Other: CHP

An industrial facility in a nonattainment area applied for a permit to replace old oil-fired boilers with two 4.1-MW gas-fired gas turbine CHP units. With the standard low- $\mathrm{NO}_{\mathrm{x}}$ combustor ( $25 \mathrm{ppm})$, the potential emissions from the CHP facility would have been lower than the emissions from the boilers. In addition, the facility at full output would displace more than 71,000 MWh of electricity from the central grid. The average emission rate in the state at that time was $2 \mathrm{lb} \mathrm{NO} / \mathrm{MWh}$ and 6.7 lbs $\mathrm{SO}_{2} / \mathrm{MWh}$. The CHP facility would displace emissions from the old boiler as well as emissions from the displaced grid electricity. The net effect of installing the project as proposed would have been an annual emission avoidance of 320 tons of $\mathrm{SO}_{2}$ and 60 tons of $\mathrm{NO}_{\mathrm{x}}$ for both on-site and off-site emissions.

The state permitting process as applied, however, did not take into account the existence of any of the CHP benefits or the onsite emission reduction and required additional add-on controls that would have made the project uneconomic. Although the project could not go forward on this basis, the facility owner continued to negotiate with the state for several years. After six years of unsuccessful negotiation, it was only with the direct intervention of the DOE that the owner was able to negotiate a two-step permit that allowed an initial $\mathrm{NO}_{\mathrm{x}}$ limit of $1 \mathrm{lb} / \mathrm{MWh}(25 \mathrm{ppm})$, declining after two years to $0.6 \mathrm{lb} / \mathrm{MWh}(15$ $\mathrm{ppm}$ ) as a test site for a new low- $\mathrm{NO}_{\mathrm{x}}$ combustion system. At the time of construction, the emission benefits were estimated to be 320 tons $\mathrm{SO}_{2}$ and 75 tons of $\mathrm{NO}_{\mathrm{x}}$ per year. The actual emissions from the turbine have been lower than projected, increasing the environmental benefit.

\subsection{No Credit for Avoided or Displaced Emissions}

DG systems often displace other on-site emitting units, either through a retrofit or because they burn waste or by-product fuels that would otherwise be flared with no useful output. Landfill gas is a good example. Landfill gas is composed largely of methane, a potent greenhouse gas, which is often flared to avoid this and other negative impacts. ${ }^{33}$ However, the flaring creates products of combustion, including $\mathrm{NO}_{\mathrm{x}}$, and creates no useful output. If the landfill gas is used to generate electricity, the generator emits $\mathrm{NO}_{\mathrm{x}}$ but the emissions from flaring are eliminated and there is a useful output. The avoided flaring emissions are rarely reflected in setting the emission limits, however. Similarly, retrofit DG technologies often replace higher emitting existing units. This is especially true of CHP.

\footnotetext{
${ }^{33}$ For example, the CARB, in its "Guidance for the Permitting of Electrical Generation Technologies" issued November 15, 2001, provided the following information and guidance regarding the use of landfill gases for electric generation. "Waste gas refers to gases generated at landfills or in the digestion of solid materials at waste water treatment plants. Both reciprocating engines and gas turbines have been used to generate electricity from waste gas. The recently promulgated NSPS (40 Code of Federal Regulation 60, subpart $\mathrm{Cc}$ and $\mathrm{WWW}$ ) requires most landfills to collect and destroy the gas produced by the landfill. At a minimum, landfill operators are required to flare the landfill gas. Many landfills have opted to develop energy projects that allow for the generation of electricity while disposing of the gas. Generally, large reciprocating engine generator sets, typically larger than $800 \mathrm{KW}$, have been used for these applications. In a few cases, gas turbines have been used instead of reciprocating engines... Overall, this category of using waste gas to generate power will have the most difficulty in attaining the goal of equivalent emissions to a central station power plant equipped with BACT. However, this difficulty should be balanced with the recognition that historically waste gases were either not collected or were flared without controls." (emphasis added)
} 
Under NSR rules, large emission sources can get credit for replacing existing emission sources through a process called "netting." Netting allows an increase in emissions to be offset by a contemporaneous decrease at the same facility, thus avoiding a major increase that triggers NSR. Smaller sources (minor sources) do not get this type of netting credit because they are already below the major source threshold. An alternative approach would be to provide credit to the DG system for the on-site reductions in the calculation of compliance with the DG system's emission limits.

\section{Example 1:}

\section{Fact Summary}

Issue: Credit for Avoided Emissions

Location: Nonattainment Area

Size: Minor Source

Technology: Combustion Turbine Other: $\mathrm{CHP}$

A developer considered the installation of a 7MW gas turbine CHP facility in a nonattainment area that required a minor source BACT determination. Although the system would have created substantial emission reductions as proposed, the state told the developer that additional add-on controls would be required (though the cost of the equipment would exceed that state's nominal cost thresholds for minor source BACT- $\$ 12,000$ to $\$ 13,000 /$ ton). The cost of these controls made the project uneconomic and it was canceled.

The proposed system would have replaced existing oil-fired boilers at an industrial facility that were emitting 72 tons of $\mathrm{NO}_{\mathrm{x}}$ per year. The CHP system with a 25 ppm low- $\mathrm{NO}_{\mathrm{x}}$ combustor and supplemental firing to increase thermal output would have emitted only 40 tons of $\mathrm{NO}_{\mathrm{x}}$ per year. Thus, there was an on-site benefit. In addition, however, the CHP system would have generated 49,400 MWh of electricity per year. The average emission rate for electric generation in the state at that time was $2 \mathrm{lb} \mathrm{NO}_{\mathrm{x}} / \mathrm{MWh}$, The on-site generation, then, would have displaced grid generation and reduced $\mathrm{NO}_{\mathrm{x}}$ emissions by approximately 49 additional tons per year, for a total reduction of 81 tons per year.

The state in question does not provide credit for offset emissions (netting) for minor sources and told the developer that add-on controls would be required to achieve 2.5 ppm $\mathrm{NO}_{\mathrm{x}}$, preferably with no ammonia slip. This would have required SCR or $\mathrm{SCONO}_{\mathrm{x}}$ technology and would have resulted in a control cost of greater than $\$ 20,000$-per-ton of $\mathrm{NO}_{\mathrm{x}}$ reduced. Because of this high cost, the project was canceled, leaving the old, dirty boilers in service.

\section{Example 2:}

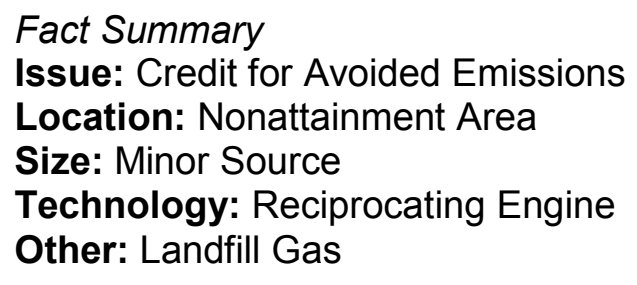

Small generators operating on landfill gas often replace flares that are otherwise used to destroy the gas. In six cases reviewed for this study, landfill gas generators all received credit for the avoided emissions in the calculation of their potential emissions increase. However, they did not receive credit in calculations of their emission limits/compliance. This oversight denies them credit for avoiding these flaring emissions. Credit of this type has been included in the California and Texas DG regulations discussed in Chapter 3. 


\subsection{Complex Case-by-Case Permitting Process Is Incompatible with the Application of Small, Standardized DG Technologies}

Permitting of new projects in most locations is based on a case-by-case analysis of emission reduction options and costs. ${ }^{34}$ This is the norm for the larger projects for which the permitting system was designed, and makes sense for projects with site-specific designs and operating characteristics. It is also economically viable to do a case-by-case analysis for a project that costs hundreds of millions of dollars. However, DG projects are very different, and thus face the following detrimental effects of being subjected to a regulatory framework designed large projects with site-specific designs and operating characteristics:

- Cost Incongruity with Mass Production Product. First, DG technologies are designed to be mass-produced rather than individually designed and field erected. The cost structure of these products rests partly on the economies of scale and scope that mass production can bring, along with inexpensive installation requirements. When the market/regulatory environment requires a DG customer to slip back into the arena of case-specific negotiations or custom engineering and analysis, one of the essential elements offered by DG to the market is quickly lost.

- Design Incongruity with Standardization Product. Second, as a corollary to the mass production for low costs element above, the standardization required for mass production also makes it impractical or impossible to change the emissions

\footnotetext{
${ }^{34}$ Even in attainment areas, if the PSD process applies, as set forth in an EPA New Source Review Workshop Manual, "During each BACT analysis, which is done on a case-by-case basis..." See http://www.epa.gov/ttn/nsr/gen/wkshpman.pdf. Also, minor sources can be subject to state BACT in both attainment and nonattainment areas.
}

characteristics of the standardized products for each application.

- Size-Insensitive Permitting Costs Have Much Higher First Cost Effects on Smaller Projects. Third, as a matter of simple arithmetic, any relatively fixed cost applied to a small project will have a much greater impact on the economic viability of the project than on a bigger project. With regard to the environmental permitting of $\mathrm{DG}$, the cost of case-by-case permitting is relatively insensitive to the size of the project. Because DG projects can be as much as 1000 times smaller than central station power plants; the cost of case-bycase environmental review can make the project uneconomical, in some cases being more than the value of the project.

As an example, assume that the cost of preparing an environmental permit in a particular jurisdiction is $\$ 25,000$, which is customarily charged to cogeneration installations of $100 \mathrm{MW}$ capacity. If the time and effort applicable to the permitting process is essentially the same for a $30 \mathrm{~kW}$ microturbine, the requirement to pay what was a very small percentage of the total cost begins to approach $100 \%$ of the cost of the generator.

These issues are most significant for the very small DG technologies that have most recently been developed and applied - many accompanied by substantial investments of federal and state energy research programs. ${ }^{35}$ As discussed previously, unfortunately these technologies are at once the most difficult to tailor to different

\footnotetext{
${ }^{35}$ See research budgets supporting fuel cells, renewables, microturbines, CHP, and other clean generation technologies and applications at federal and state organizations: US DOE http://www.energy.gov/; California Energy Commission, http://www.energy.ca.gov/; New York State Energy Research \& Development Authority (NYSERDA) http://www.nyserda.org/
} 
requirements and the most sensitive to increased permitting costs.

\section{Example 1:}

Fact Summary

Issue: Complex Permitting

Location: Nonattainment Area

Size: Minor Source

Technology: Reciprocating Engine

A developer of commercial building projects is using a $200 \mathrm{~kW}$ natural gas engine. The engine uses a 3-way catalyst to meet $\mathrm{NO}_{\mathrm{x}}$ emission limits and reduce $\mathrm{CO}$ and unburned hydrocarbons including air toxics. The current permitting process requires each engine to be separately tested for each of the regulated pollutants. Testing takes two to three days per site. The cost of the test procedure is $\$ 3,000$ to $\$ 5,000$ compared to about $\$ 160,000$ for the engine itself.

After 12 projects, the results of the tests showed that emissions were within the required limits for each engine. In some cases, the pollutant levels have been below the detection levels of the testing. However, the permitting authorities continue to require that each engine be separately tested even though they are identical engines and continue to show consistent, complying test results. This regulatory practice is being applied to multiple installations in the same jurisdiction, and even multiple engines at the same facility must be separately tested.

The testing requirement increases the cost of the permitting and development cost for the projects - not least of which is the time and attention needed to add this effort to the project plan for each engine. The developer must propose a testing protocol for each site that must be reviewed by the local agency. The developer has proposed that the permitting agencies recognize the performance of these engines or at least simplify the testing, but these suggestions have not been adopted to date.

\section{Example 2:}

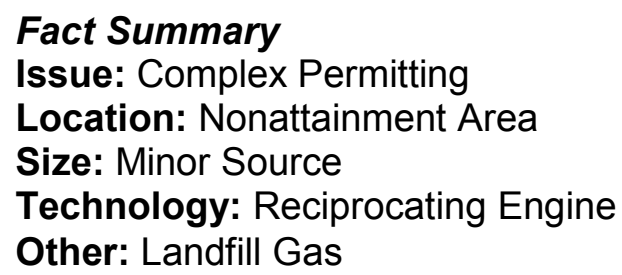

Operators of a landfill in an ozone nonattainment area installed two $750-\mathrm{kW}$ reciprocating engine generators running baseload on landfill gas that had previously been flared. The state requires a case-bycase minor-source BACT process for all projects greater than $3 \mathrm{MMBtu} / \mathrm{hr}$ heat input (about 250 to $300 \mathrm{~kW}$ ). Although there are a variety of $\mathrm{NO}_{\mathrm{x}}$ control technologies available for natural gas engines, most do not work well with landfill gas because of impurities in the gas. Lean-burn, low- $\mathrm{NO}_{\mathrm{x}}$ combustion is the most common $\mathrm{NO}_{\mathrm{x}}$ control requirement for such projects.

Nevertheless, the state required a detailed evaluation and review of all available control technologies before approving a lean-burn combustion system that is commonly used in landfill gas applications. Although the developer said that the state agency was very helpful in the permitting process, the technology review and permitting process took eight to nine months to complete The additional cost required by the process was approximately $\$ 20,000$ for the permitting and $\$ 5,000$ for the BACT analysis. This is only a small percentage of the generation cost, but nevertheless adds to the cost of the system development. 


\subsection{No Consideration of Very High Unit Costs of Stringent Emission Limits for Small, Clean Generators}

The emission control requirements for large emission sources in most parts of the country are based on the control cost -per-ton of emission reduction. Under the BACT requirement, the source must apply the best control that does not exceed a control cost threshold. This process is intended to limit the cost of required emission reductions while ensuring a reasonable level of control. The BACT cost threshold for large sources varies from state to state but ranges from a few thousand dollars -per-ton of reduced $\mathrm{NO}_{\mathrm{x}}$ emissions up to $\$ 10,000$ to $\$ 15,000 /$ ton in areas with greater air quality concerns. ${ }^{36}$

While large emission sources, including traditional large generators, have the opportunity to limit their cost exposure through the BACT process, emission limits for small sources are sometimes fixed based on the technologies applied for larger sources. That is, if a state determines that SCR, for example, is a cost-effective emission control technology for large gas turbines, it may set a fixed emission control requirement at an equivalent level of control for much smaller generators. While this approach can eliminate the "case-by-case" issue, it can be an empty victory if the state consequently sets a required control cost that is higher than that set for larger sources and makes small projects uneconomic.

The cost of add-on emission controls is not linear with size. ${ }^{37}$ It is typically significantly

\footnotetext{
${ }^{36}$ California applies a state "BACT" criterion with a higher cost threshold. However, most of California is not in attainment for ozone and the state BACT is commonly recognized as equal to LAER in other parts of the country.

${ }^{37}$ The California Energy Commission, responsible for the siting of energy generation facilities in California confirmed this analysis informally in a November 2001 publication, which stated, in part, "The best NOx performance by most commercially available gas turbines is around 15 parts per
}

higher for small sources due to the diseconomies of scale of control technologies originally developed for larger generators. Thus, this technology-based approach often sets emission control requirements for small sources that are many times more costly on a per unit basis than would be required for large sources.

Example 1 in Section 4.3 describes a very similar case in which the high cost cased an environmentally beneficial project to be cancelled.

\section{Example 1:}

\section{Fact Summary \\ Issue: High Unit Cost of Control \\ Size: Minor Source \\ Technology: Combustion Turbine \\ Other: CHP}

A high-technology manufacturing facility in a nonattainment area applied for a permit for a 5-MW gas turbine-based CHP facility. The facility proposed a $0.6 \mathrm{lb} / \mathrm{MWh} \mathrm{NO}_{\mathrm{x}}$ level (15 ppm) based on a developmental low$\mathrm{NO}_{\mathrm{x}}$ combustion technology. The project would be a minor source (13 tons per year potential increase in emissions).

The state has a case-by-case minor source BACT process with a cost threshold of $\$ 12,000$ to $\$ 13,000 /$ ton. However, in this case the state air board required the application of newly developed $\mathrm{SCONO}_{\mathrm{x}}{ }^{\mathrm{TM}}$

million (ppm). Some air quality management districts require a NOx limit of 2 parts per million for new sources (at 15\% O2). In regions with the 2-ppm limit, new gas turbine installations require additional equipment to remove NOx from the exhaust. These exhaust clean-up systems are expensive to build and operate, they penalize the fuel-toelectricity performance of the engine, and they introduce additional potential for unreliability in the overall system. Although utility-scale gas turbines justify the cost and complexity of exhaust clean up systems, gas turbines with a nominal size of $5 \mathrm{MW}$ cannot."(Emphasis added) California Energy Commission PIER Program, Energy Update, "Low Emissions Gas Turbines: Cheaper Energy, Cleaner Air." November 2001. 
emission control technology rather than accepting the use of the low- $\mathrm{NO}_{\mathrm{x}}$ combustion technology inherent in the turbine as the control technology. $\mathrm{SCONO}_{\mathrm{x}}$ at this time had only been applied on one or two much larger systems.

Due to the critical requirement for on-site steam and electric generation at the facility, the developer was forced to acquiesce to the state requirement and added the $\mathrm{SCONO}_{\mathrm{x}}^{\mathrm{TM}}$ at an additional capital cost of $\$ 1$ million, corresponding to an annual cost of $\$ 496,000$ per year. Assuming a $92 \%$ reduction, the addon controls reduce potential emissions by 12.4 tons per year. This corresponds to a cost of almost $\$ 40,000 /$ ton $\mathrm{NO}_{\mathrm{x}}$ reduced. This is several times the state's stated threshold for minor source BACT determination. However, in actual practice the cost apparently was not considered in setting the requirement for "additional control." The state has since stepped back from the $\mathrm{SCONO}_{\mathrm{x}}$ requirement for future projects but still requires similar levels of control using other technologies.

\section{Example 2:}

Fact Summary

Issue: High Unit Cost of Control

Location: Nonattainment Area

Size: Minor Source

Technology: Various

In 2000, the California State Legislature passed Senate Bill 1298. SB1298 requires CARB to set emissions limits for very small generators (typically less than $100 \mathrm{~kW}$ ) that by 2007 are equivalent on an output basis to the best large central station generators. This approach does not account for the fact that large prime movers are intrinsically more efficient than small generators. It also does not account for the economies of scale for add-on pollution control technology for large generators. Finally, it does not consider that the add-on $\mathrm{NO}_{\mathrm{x}}$ control technologies used on large projects are too complex for small on-site applications and/or use toxic or noxious reagents that would not be acceptable in these applications.

CARB has developed a rule implementing $\mathrm{SB} 1298$ that requires a $\mathrm{NO}_{\mathrm{x}}$ emission level of $0.07 \mathrm{lb} \mathrm{NO} / \mathrm{MWh}$ for small $\mathrm{DG}$ equipment in California starting in 2007. No conventional (non-fuel cell) DG equipment currently available or currently envisioned will be able to meet this limit. SB1298 is an example of an approach that while directed at the specific challenges presented by DG to traditional air regulation, nevertheless does not seem to consider the physical limitations of small generating equipment. One justification for these aggressive limits is to set "stretch goals" that will stimulate technology advances. However, they may have the opposite effect and discourage research and development if the goals are so aggressive that industry believes them to be unattainable.

\subsection{No Credit for Pollution Prevention in Determination of Control Requirements}

The traditional approach to new source permitting focuses on "add-on" control requirements rather than pollution prevention approaches such as technology designed for low emission requirements. The BACT process, for example, focuses on what control technology can be added to an emissions source, rather than on the actual emission level that may already be low because of inherently clean technology. The "safety valve" for BACT is the cost of control. As discussed above, some states establish a cost threshold for the BACT control technology above which a particular control technology is theoretically not required. In principle, as the underlying technology gets cleaner, the cost of applying add-on controls become more expensive per 
ton of emissions since there is less and less pollution to be removed for the control technology investment. Thus, at some point, inherently clean technologies should be recognized by the BACT process as "clean enough."

However, some states are focused on more addon control equipment and avoid crediting the lower emitting technology by using a higher value for the baseline emissions. This causes the cost-of-control calculation to yield a lower value that makes the add-on control meet the cost threshold. Besides creating an economic barrier to technologies that are based on pollution prevention, this practice negates the value of successful technology advances initiated because of a desire to accomplish pollution prevention.

Ironically, Pollution Prevention (P2) is a significant program at the EPA, with considerable business support. The EPA P2 Web site states that:

"P2 is also a vehicle for 'reinventing' traditional Agency programs and devising innovative alternative strategies to protect public health and the environment. It is a key element of new EPA initiatives to focus attention on reducing risks from persistent, bioaccumulative toxic pollutants in the air, in water, and on land; to promote environmental justice and urban environmental quality; to empower state and tribal programs; to lower the incidence of climate change; and to demonstrate the results and benefits of our labors. In addition, EPA is incorporating P2 into programs that encourage environmentally preferable purchasing and corporate ecoefficiency. $\mathrm{P} 2$ is a building block for private sector environmental performance and sustainability."

As discussed above, DG technologies have largely focused on pollution prevention as their primary means of pollution control, with significant success. This includes the use of clean fuels and advanced combustion design and control to minimize emissions. The focus on pollution prevention rather than customized pollution controls is partly due to the underlying strategic advantage of mass production, but is also due to the many DG applications that are simply not appropriate for the use of add-on control technologies, either because of the complicated nature of current control technologies designed for large generation installations, or because the hazardous or noxious reagents required in some technologies are not acceptable in DG markets such as residential or commercial applications. The regulatory practices that do not recognize pollution prevention are not only inconsistent with important national and state environmental goals, but they also create an inappropriate burden for DG technologies.

\section{Example:}

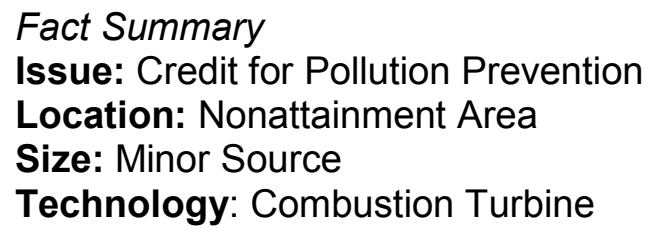

A gas pipeline company attempted to obtain an air quality permit to install a gas turbine compressor drive in a nonattainment area. Although this was not a power generation application, the technology and the regulatory process were the same as would be applied for a small combustion turbine power project. The turbine was a minor source with a low- $\mathrm{NO}_{\mathrm{x}}$ combustor $(25 \mathrm{ppm})$. The state requires a case-by-case application of the minor source BACT requirement with a $\$ 12,000 /$ ton cost threshold.

The owner performed a BACT analysis that showed that state-recommended add-on controls (SCR) would exceed the cost threshold. The state permitting authority, 
however, required that the BACT analysis be performed using an emissions baseline of 105 ppm, apparently because that was what turbines without a low- $\mathrm{NO}_{\mathrm{x}}$ combustor could be expected to produce. On this basis, using the higher level of emissions over which to spread the cost of the add-on controls resulted in a per ton cost which would be "cost effective," even though it was recognized that the turbine would never emit at this level.

For example, a 5-MW turbine at $25 \mathrm{ppm} \mathrm{NO}_{\mathrm{x}}$ has potential emissions of 22 tons of $\mathrm{NO}_{\mathrm{x}}$ per year. An SCR system that removes $90 \%$ of the $\mathrm{NO}_{\mathrm{x}}$ will reduce emissions by 20 tons. If the SCR costs $\$ 192 / \mathrm{kW}$ or $\$ 352,600 /$ year, that is $\$ 17,700 /$ ton removed-higher than the cost threshold. If the baseline emissions are arbitrarily assumed to be $105 \mathrm{ppm}$, however, then the potential emissions would be 95 tons per year and the $90 \%$ reduction would be 83 tons per year. For the same capital cost, this yields a cost effectiveness of only $\$ 4,200 /$ ton - well within the threshold.

The company objected to the approach and after extended negotiations the company was able to obtain a permit at $15 \mathrm{ppm}$ without SCR, although the state has not officially changed its analysis requirement.

This approach to BACT analysis is not consistent with federal permitting guidance and is a threat to the continued development of pollution prevention technology as an alternative to post-combustion control devices. 


\section{Chapter 5. Recommendations and Conclusions}

\subsection{Recommendations}

Chapter 4 identified a number of ways in which air quality permitting inappropriately impedes the development of environmentally beneficial DG by failing to recognize the environmental benefits offered by these technologies or failing to correctly address their size or other unique characteristics. Four structural changes in air quality regulation and one institutional program can address these issues:

- Develop uniform, achievable national air emission standards for DG.

- Provide credit for CHP in air quality permitting.

- Provide credit for avoided/offset emissions in air quality permitting.

- Incorporate market-based regulatory structures (emission trading programs).

- Provide outreach and training for air regulators and DG developers.

\subsubsection{Develop Uniform, Achievable Environmental Standards for DG}

DG technologies could be more appropriately regulated with uniform environmental standards designed to deal with the issues specific to DG. Such standards should be:

- Uniform

- Achievable

- Output-based

- Include pre-certification

These characteristics are discussed below.

Uniform-DG technologies are mass produced for use in a "plug and play" mode in a wide variety of applications. The emission characteristics cannot be tailored to individual applications. The cost of add-on pollution control equipment is very high for small generators and such systems may be impractical for the target markets because of their complexity or operational requirements. Finally, the cost of case-bycase permitting is prohibitive for small generators that are intended to be purchased and installed as off-the-shelf systems.

It is not feasible for small DG systems to meet different emissions limits in each application, and it is not economical for developers to be required to justify their environmental performance for each individual project. Establishing uniform, output-based standards would address several of the issues identified in this report. It would replace complicated case-by-case permitting with a simple but effective regulatory structure. This is important not only to industry and users, but to regulators who would otherwise be overwhelmed with the burden of permitting a great number of small generators. If uniform, output-based standards are established, manufacturers can design and build equipment to meet those standards and consumers can install and use the equipment easily and efficiently.

Achievable - California and Texas have established uniform emission standards for DG, but it is not clear that these standards can be achieved by available technologies. While uniform standards are an important concept, they are not useful if they cannot be achieved. Standards should both protect clean air and be achievable.

Output-Based-The standards should be output-based and performance-based in units of $\mathrm{lb} / \mathrm{MWh}$. This format provides credit for energy efficiency and pollution prevention and allows manufacturers to use all possible approaches to minimize emissions. Outputbased standards are also more conducive to proper crediting of CHP technologies. 
Include Pre-certification-DG equipment is much more similar to mobile source equipment than to central station power plants in its size, manufacturing, and application. The regulatory model for mobile sources is a good model for DG. Emissions from some portable electric generator emissions (small engines) are already regulated as part of the non-road engine regulation with uniform standards and precertification. A similar approach for small stationary generators would provide environmental security while expanding the environmental benefits of DG application. Appropriately set uniform standards with precertification options could allow DG technologies to be mass-produced with the certainty that they could be easily permitted and installed. At the same time, such uniform standards would ensure that all DG meets minimum environmental standards that ensure environmental benefits. Finally, appropriately phased-in standards would encourage and allow manufacturers to improve the environmental performance of DG technologies over time with the assurance that those improvements will have a place in the market.

\subsubsection{Provide Credit for CHP}

Any environmental regulation of DG should recognize the benefits of CHP by giving credit for both the thermal and electric output. This can be done as a credit against the emissions of the DG project either as a netting reduction or as part of calculating compliance with fixed emission limits.

As discussed earlier, CHP is the most readily available method of increasing the overall efficiency of the nation's thermal and electric generation infrastructure for all fuels and most technologies. However, very few existing regulatory programs give direct recognition or credit for the environmental benefits provided by CHP. ${ }^{38}$ None of the case studies evaluated

\footnotetext{
38 "Certification of Combined Heat and Power Systems: Establishing Emissions Standards." Page 3, Anna Monis Shipley, Nathanael Green, Katie McCormack, Jia Li, and R.
}

for this report received credit for CHP. In many cases, the characteristics of a CHP facility create increased complexity in permitting or are interpreted in ways that make the permitting more challenging.

Under a uniform, performance-based approach such as recommended above, the CHP project could be permitted without such complications. In addition, explicit credit can be provided for the increased efficiency. This can be done in several ways. The Texas general permit for small generators provides credit for the thermal output in the calculation of the output-based emission rate. ${ }^{39}$ A more rigorous approach would provide direct credit for the avoided emissions from the steam generator that the CHP system replaces. The American Council for an Energy Efficient Economy $(\mathrm{ACEEE})^{40}$ has described one approach to this calculation.

\subsubsection{Provide Credit for Avoided/Offset Emissions}

In addition to giving credit for avoided boiler emissions, regulations should give credit for other emissions offset or avoided by DG systems. This includes credit for the beneficial use of waste or by-product fuels that would otherwise be flared or incinerated without useful output. The DG facility should get credit for the avoided emissions as a credit against compliance requirements.

DG retrofit projects should also be credited for the avoided emissions of facilities that they replace on-site, either as a netting credit or a credit against compliance limits. DG projects often replace existing emission

Neal Elliott. September 2001 Report Number IE014 American Council for an Energy-Efficient Economy, 1001 Connecticut Avenue, N.W., Suite 801, Washington, D.C. 20036 202-429-8873 phone, 202-429-2248 fax, http://www.aceee.org/

${ }^{39}$ http://www.tnrcc.state.tx.us/permitting/airperm/nsr_permi $\frac{\text { ts/files/segu final.pdf }}{40}$

${ }^{40}$ Ibid, note 38 . 
sources, usually with more efficient and lower emitting technologies. Recognizing this benefit through regulatory credit will create a greater incentive for such activity and promote the wider application of environmentally beneficial DG and replacement of old, high emitting sources. This type of regulatory credit has been included in the Texas DG rule and is being discussed as the basis of a collaborative effort to develop a consistent national approach for air quality regulation of DG. ${ }^{41}$

\subsubsection{Incorporate Market-based Regulatory Structures}

Emission trading has been shown to be a costeffective, flexible regulatory approach for reducing emissions and encouraging the use of clean technologies. Accelerating the development of emissions trading programs for all sources including DG would be one way to limit DG-related emissions and encourage the development of clean DG technologies. The EPA and the states have various emissions trading programs underway and under consideration. These trading markets are designed to provide financial credit to very clean projects and allow emission reductions to be achieved in the most cost-effective way.

Trading programs can also offer value to DG projects that have lower than average emissions and thereby encourage the development of lower-emitting technologies by allowing them to create tradable emission allowances. Extending the benefits of these programs to clean DG projects requires the inclusion of four important components:

- Opt-in option for small sources

- Aggregation of sources

- Frequent, output-based allowance allocation

- Simplified monitoring for small sources.

\footnotetext{
${ }^{41}$ This effort is being led by the Regulatory Assistance Project (RAP), with support from DOE. For additional information, see the RAP Web site http://www.rapmaine.org/.
}

Opt-in option for small sourcesAllowance trading programs have so far been focused on large emission sources for a variety of reasons. Among other reasons, regulators do not want to have to track the very large number of small emission sources that may not actually wish to participate in the trading program. However, trading programs should have simple opt-in programs to allow participation by small sources that can create value in the program. This would provide an opportunity for environmental benefits and lower control costs without creating a burden on the program or on sources that will not benefit from the program.

Aggregation of sources- It is administratively difficult for small DG to participate in existing emission trading programs because of the design focus of these programs on larger generating sources. For example, the allowances are typically denominated in tons and require a variety of administrative functions for participating sources. Many DG facilities might not generate or consume a whole ton of emissions and would be too small to cover the administrative costs of participation. However, a number of DG facilities or projects could be aggregated to function on an appropriate scale to buy or sell

allowances in the trading program. Emission trading programs should allow aggregation of small sources for this purpose.

\section{Simplified monitoring for small sources-} Accurate emission monitoring is a key component of emission trading programs. Companies and regulators need to know that the reductions they are buying and selling are real and accurately accounted for. The current emission trading programs require the use of sophisticated and costly continuous emission monitoring systems (CEMS). These would be too costly and inappropriate for small units with very low 
emissions. Although some alternative measurement protocols for clean units exist in the current trading programs, broader inclusion of DG projects would require specifying additional approaches for small clean sources. These could be tied to the pre-certification program or take advantage of alternative monitoring technologies such as parametric emissions monitoring systems (PEMS).

\section{Frequent, output-based allocation-In} allowance trading programs, the initial allocation of allowances to affected sources is a critical factor in determining whether projects get value from the program. Some trading programs, such as the acid rain $\mathrm{SO}_{2}$ trading program, allocate all of the allowances once and forever to old power plants that were in existence before the program began. New, clean plants have no opportunity to use their low emissions to create value in the trading program. In fact, they must purchase allowances from the older, higher emitting plants in order to comply with the program. In other programs, new sources can receive allowances at a lesser rate than old sources and the reallocation of allowances may be very infrequent (every 5 to 10 years), delaying the entry of new sources into the program. Future emission trading programs should include frequent reallocation of allowances in order to quickly bring new sources into the program. The allocation should be done on an equal basis for all generators based on the thermal and electric energy generated by each unit. Outputbased allocation provides a simple method for equal allocation, rewards more efficient generators, and allows easy inclusion of renewable generators in the trading program.

\subsubsection{Provide Outreach and Training for Regulators and Developers}

Most environmental regulatory programs are administered by the states and are chronically understaffed and underfunded. State regulators have little time and few resources to come to grips with new technologies and new modes of industrial operation. DG represents both.

On the other hand, some DG developers are not familiar with many aspects of air quality regulation. Some of the complaints registered by DG developers stem from a lack of knowledge of air regulatory programs and requirements.

The successful implementation of DG would be greatly assisted by an integrated program of outreach and education for state regulators on DG technologies, applications, benefits and permitting issues. A parallel program for DG developers would provide a complementary benefit. If uniform national emissions standards for DG were developed, they would provide an excellent context for such an integrated outreach program.

\subsection{Conclusions}

DG has the potential to provide energy, environmental, and commercial benefits in a variety of applications in which the central generation grid does not and cannot provide the same efficiency, reliability, or customization to user needs. This study recommends specific changes in the structure of existing air quality regulation that could prevent unnecessary constraints on the development and expansion of distributed generation and allow the realization of the potential environmental benefits of these technologies. New technologies, new energy regulatory structures, changing user needs, and the continuing penetration of modern electronic devices into our infrastructure are creating these opportunities. To achieve these potential benefits, however, environmental regulation must also keep pace with changing technology, markets, and energy regulations. 
Clean Air Act: The 1970 Clean Air Act, as amended, is a federal law covering the entire country; however, the states do much of the work to carry out the Act. For example, a state air pollution agency holds a hearing on a permit application by a power or chemical plant or fines a company for violating air pollution limits. Under this law, EPA sets limits on how much of a pollutant can be in the air anywhere in the United States. This ensures that all Americans have the same basic health and environmental protections. The law allows individual states to have stronger pollution controls, but states are not allowed to have weaker pollution controls than those set for the whole country. The law recognizes that it makes sense for states to take the lead in carrying out the Clean Air Act, because pollution control problems often require special understanding of local industries, geography, housing patterns, etc. States have to develop state implementation plans (SIPs) that explain how each state will do its job under the Clean Air Act. A SIP is a collection of the regulations a state will use to clean up polluted areas. The states must involve the public, through hearings and opportunities to comment, in the development of each state implementation plan. EPA must approve each SIP, and if a SIP isn't acceptable, EPA can take over enforcing the Clean Air Act in that state. The United States government, through EPA, assists the states by providing scientific research, expert studies, engineering designs, and money to support clean air programs.

Combined-cycle gas turbine (CCGT): In a combined-cycle system, a combustion turbine extracts shaft power from the combustion of fuel and spins an electric generator to generate electricity. The hot exhaust gases from the combustion turbine are then routed to a separate "waste heat recovery unit." The waste heat recovery unit extracts heat from the gases and generates steam for use in a steam turbine, which in turn provides shaft power to spin an electric generator and generate electricity.

\section{Combined heat and power: See CHP}

Combustion turbines: Conventional combustion turbine generators are a very mature technology related to, but originating from different designs, the turbines used to power aircraft, and their descendants, the aeroderivative turbines. Originally, nonaeroderivative turbines tended to be heavier, and thus more suited for heavier use applications. They typically range in size from about $500 \mathrm{~kW}$ up to $25 \mathrm{MW}$ for DG, and up to approximately $250 \mathrm{MW}$ for central power generation. They are fueled by natural gas, oil, or a combination of fuels ("dual fuel"). Modern single-cycle combustion turbine units typically have efficiencies in the range of $25 \%$ to $38 \%$ at full load. Efficiency is somewhat lower at less than full load.

CEMS: Continuous emission monitoring systems

Criteria pollutants: The Clean Air Act requires EPA to set NAAQS for pollutants considered harmful to public health and the environment. The Clean Air Act established two types of national air quality standards. Primary standards set limits to protect public health, including the health of "sensitive" populations such as asthmatics, children, and the elderly. Secondary standards set limits to protect public welfare, including protection against decreased visibility, damage to animals, crops, vegetation, and buildings. The EPA Office of Air Quality Planning and Standards (OAQPS) has set NAAQS for six principal pollutants, which are called "criteria" pollutants. They include carbon monoxide $(\mathrm{CO})$, nitrogen dioxide $\left(\mathrm{NO}_{2}\right)$, ozone $\left(\mathrm{O}_{3}\right)$, lead $(\mathrm{Pb})$, particulates ( including total particulate, $\mathrm{PM}_{10}$ - particles with diameters of 10 micrometers or less; $\mathrm{PM}_{2.5}$ - particles with diameters of 2.5 micrometers or less), and $\mathrm{SO}_{2}$. 


\section{Glossary}

ACEEE: American Council for an Energy Efficient Economy, see http://www.aceee.org/.

Aggregation for wholesale application: One of the business models for DG involves the aggregation of a number of DG resources by an "aggregator" who then contracts with a buyer of energy such as a Regional Transmission Organization for energy or load management services.

Attainment: Refers to areas of the United States that have met air quality standards for human health set in the Clean Air Act. See page 22 for a map of ozone nonattainment areas.

BACT: Best available control technology-BACT represents an emission limit based on the maximum degree of reduction of each pollutant as described in regulations under NSR/PSD requirements in attainment areas. The determination of BACT takes into account energy, environmental, economic effects, and other costs.

CAEM: Center for the Advancement of Energy Markets, see http://www.caem.org/

California Air Resource Board (CARB): California state air regulatory agency, see www.arb.ca.gov/homepage.htm.

Case-by-case permitting: Individually analyzed, negotiated, and permitted regulation, as opposed to the issuance of standard permits if certain conditions are met, or, as is done with motor vehicles, regulation through national standards.

Catalytic combustion: This approach uses a catalyst to flamelessly oxidize fuel and release its heat at a temperature below the $\mathrm{NO}_{\mathrm{x}}$ formation temperature. Catalytic combustion has been demonstrated for combustion turbines and has achieved very low- $\mathrm{NO}_{\mathrm{x}}$ levels. The cost and durability have yet to be demonstrated but some companies are starting to offer turbines using this technology.

Central station plants: The model upon which the U.S. electric industry has been built over the last 100 years, initially based on the economies of scale available as generation plants were built bigger and bigger based on improved materials. This ability to achieve economies of scale may have peaked in the second half of the $20^{\text {th }}$ Century, and the average size of generation plants built in the United States has been declining. Additionally, new technologies for generating, controlling, and integrating smaller generation into the electric system are now challenging the exclusive reliance on ever bigger "central station" plants, with their need for transporting the power (through transmission and distribution facilities) to the loads. Dispersing the generation sources makes the use of the heat otherwise wasted in the generation process much more likely to be utilized for process or thermal purposes.

CHP: Combined heat and power also sometimes referred to as co-generation, although CHP may also involve cooling. The sequential generation of electric and thermal energy from the same heat input. 
Distributed generation or DG: Relatively small electricity generator(s) located at or near the place where the generated electricity is used.

DOE: The U.S. Department of Energy, see http://www.energy.gov/.

EIA: The Energy Information Administration, created by Congress in 1977, is a statistical agency of the DOE. See http://www.eia.doe.gov/.

Electric grid: The facilities through which electricity is transported from where it is generated, typically large central station plants, to the user, through transmission (high voltage) and distribution (medium voltage) wires, and the associated substations, switches, transformers, and other necessary equipment.

Emergency generation: Refers to use of DG for provision of electricity to critical uses of the customer. Specific laws, codes, and standards often require the provision of emergency generators for certain uses. For example, the National Electrical Code 517-13, requires all hospitals and critical care facilities to have backup power systems that start automatically and are up and running at full capacity within 10 seconds after power failure. The National Building Code of the National Fire Protection Association requires high-rise buildings to have immediately available emergency power generation for elevators. This ensures that passengers will not be stranded on elevators on upper floors in the event of a fire or other emergency. States typically adopt the national codes. For example, Section 403.8 of the Massachusetts State Building Code (MSBC), 6th Edition, states that standby power is required for elevators in high rise buildings, and that the power shall be provided for at least one elevator to serve all floors and be transferable to any elevator.

Emission: The release or discharge of a substance into the environment. Generally refers to the release of gases or particulates into the air.

Emission trading: See Market-based regulatory structures

EPA: The U.S. Environmental Protection Agency, see http://www.epa.gov/.

ESCos: Energy Service Companies, often offering energy conservation and load management products and services in exchange for a portion of the savings achieved.

Fossil-fueled DG technologies: DG technologies directly or indirectly using the energy from oil, gas, coal or other fossil-based fuels.

Fuel cells: Fuel cells produce electricity through an electrochemical reaction rather than combustion. While today they remain more expensive than conventional power generating equipment, fuel cells provide efficient, reliable power with minimal emissions.

kW: kilowatt or 1000 watts (an instantaneous measurement of power)

kWh: kilowatt-hour-1000 watt-hours (a measurement of energy) 
LAER: Lowest achievable emission reduction - The standard of emission control for major new sources subject to nonattainment new source review. Requires the greatest reduction demonstrated in practice or included in a permit regardless of cost.

Landfill: A method for final disposal of solid waste on land. The refuse is spread and compacted and a cover of soil applied so that effects on the environment (including public health and safety) are minimized. Under current regulations, landfills are required to have liners and leachate treatment systems to prevent contamination of ground-water and surface waters. An industrial landfill disposes of nonhazardous industrial wastes. A municipal landfill disposes of domestic waste including garbage, paper, etc. This waste may include toxins that are used in the home, such as insect sprays and powders, engine oil, paints, solvents, and weed killers.

Lean-burn combustion: The formation of $\mathrm{NO}_{\mathrm{x}}$ is primarily linked to a high-temperature reaction between oxygen and nitrogen in the combustion air. Low- $\mathrm{NO}_{\mathrm{x}}$ combustion technologies try to minimize this reaction by limiting the peak combustion temperature and by controlling the availability of oxygen at times when $\mathrm{NO}_{\mathrm{x}}$ could be formed. In many cases, extra combustion air is used to cool the flame. This is referred to as "lean" combustion because there is more combustion air than is needed to burn the available fuel. In reciprocating engines these techniques are referred to as "lean-burn combustion." See also "Pollution prevention."

Major sources: New or modified sources of emissions that exceed certain potential emissions thresholds are called "major sources" and are subject to the federal NSR program. The manner in which the NSR permitting process applies to a proposed project is determined by the "potential emissions" of the affected source. "Potential emissions" means the total annual emissions if the source were to run at full capacity for an entire year.

Market-based regulatory structures: Innovative approaches to regulation using market mechanisms to optimize an element of the regulatory objectives. Market-based mechanisms can include a variety of economic or market-oriented incentives and disincentives, such as tax credits, emissions fees, or tradeable emissions limitations (emissions trading for short). For example, the innovative, market-based $\mathrm{SO}_{2}$ allowance trading component of the Clean Air Act Acid Rain Program allows utilities to adopt the most cost-effective strategy to reduce $\mathrm{SO}_{2}$ emissions at units in their systems.

Megawatt (MW): One million watts. (An instantaneous measurement of power)

Megawatt-hour (MWh): One million watt-hours. (A measurement of energy)

Microturbines: Microturbines are a new type of combustion turbine being used for mobile and stationary energy generation applications. They are small combustion turbines, approximately the size of a refrigerator, with outputs of $25 \mathrm{~kW}$ to $500 \mathrm{~kW}$, and can be located on sites with space limitations for power production. Microturbines are composed of a compressor, combustor, turbine, alternator, recuperator, and generator. Waste heat recovery can be used in CHP systems to achieve energy efficiency levels greater than $80 \%$. In addition to power generation, microturbines offer an efficient and clean solution to direct mechanical drive markets such as compression and air conditioning. 
Minor source review: If emissions are below the major source threshold in the New Source Review process, sources are subject to "minor source review" at the state level. The requirements of minor source review vary greatly from state to state. The manner in which the NSR permitting process applies to a proposed project is determined by the "potential emissions" of the affected source. Potential emissions means the total annual emissions if the source were to run at full capacity for an entire year.

MMBtu: million British thermal units - a measure of energy. $3.413 \mathrm{Btu}=1 \mathrm{kWh}$

NARUC: National Association of Regulatory Utility Commissioners. The National Association of Regulatory Utility Commissioners (NARUC) is a nonprofit organization founded in 1889. Its members include the governmental agencies that are engaged in the regulation of public utilities and carriers in the fifty States, the District of Columbia, Puerto Rico and the Virgin Islands. NARUC's member agencies regulate the activities of telecommunications, energy, and water utilities.

National Ambient Air Quality Standards (NAAQS): The NAAQS, as promulgated by the EPA from time to time, form the foundation of the U.S. air quality program. The NAAQS set standards for 6 pollutants, called "criteria pollutants."

National Energy Policy: The report issued by the National Energy Policy Development Group, chaired by Vice President Dick Cheney in May 2001. See http://www.whitehouse.gov/energy/.

New Source Review (or "NSR"): The New Source Review program was enacted by Congress as part of the Clean Air Act Amendments of 1977. The goal of the NSR program is to minimize air pollution from large new and modified stationary sources. The NSR permit program for major sources has two different components - one for areas where the air pollution exceeds health standards, and the other for areas in which the standards are being achieved. Under the Clean Air Act, geographic areas (e.g., counties or metropolitan statistical areas) are designated as "attainment" or "nonattainment" with the health-based NAAQS - the air quality standards which are set to protect human health. The permitting program for sources located in attainment areas is called Prevention of Significant Deterioration (PSD) and for sources located in nonattainment areas it is the nonattainment NSR program. A major difference in the two programs is that the control technology requirement is more stringent in nonattainment areas and is called the Lowest Achievable Emission Rate (LAER). On the other hand, in attainment areas, a source must apply Best Available Control Technology (BACT) and the statute allows consideration of cost in weighing BACT options. Although nonattainment NSR technically refers to the program applicable to nonattainment areas, NSR is used generically to refer to the PSD/NSR programs.

Nonattainment areas: Refers to areas of the United States that have not met air standards for human health by deadlines set in the Clean Air Act. More technically, "any area that does not meet (or that contributes to ambient air quality in a nearby area that does not meet) the national primary or secondary ambient air quality standard for the pollutant."

NYSERDA: New York State Energy Research \& Development Authority

PAFC: phosphoric acid fuel cell 
Particulate matter (PM): The solid/liquid particles which are in the air and are usually made up of the chemicals or materials from the original source. PM impacts the environment by decreasing visibility and harming crops and plant life. Also, because PM can be very small, it is easily breathed in and trapped in the lungs, causing various health problems. Generally, any activity that involves burning of materials or any dust generating activities are sources of PM. PM can come from fireplaces and cars driving on unpaved roads as well as the smoke from large industrial plants.

Peak shaving: A load management approach that reduces overall energy costs by reducing the peak amount of electricity demanded. Where electric rates include an element relating to the maximum demand, the control of the customers' maximum demand can result in significant savings. DG can be used to generate power during such times of "peak" use, thus "shaving" the peak demand seen by the utility meters.

Plug and play mode: A somewhat misleading metaphor borrowed from the computer industry by some distributed energy advocates. The term is intended to refer to the increasingly easy purchase and installation of distributed technologies into grid-connected systems. Some suggest that DG should be like plugging in a refrigerator.

$\mathbf{P M}_{2.5}$ : Particulate mater smaller than 2.5 microns in diameter. EPA has promulgated ambient air quality standards for $\mathrm{PM}_{2.5}$ as part of the NAAQS. See criteria pollutants, NAAQS.

Pollution prevention: An approach to environmental regulation that is based on the realization that preventing pollution can be much less costly and disruptive than cleaning up after the emission or mitigating the damages. For example, designing a generation process to create less $\mathrm{NO}_{\mathrm{x}}$ by burning at a lower temperature, rather than attempting to clean up the otherwise generated $\mathrm{NO}_{\mathrm{x}}$ through the use of add-on catalytic controls.

Post-combustion $\mathrm{NO}_{\mathrm{x}}$ control: see SCONOx and selective catalytic reduction (SCR)

ppm: Parts per million. A measure of concentration often used to measure emissions from combustion turbines.

Prevention of Significant Deterioration (PSD): The permitting program applied in attainment areas.

Power quality: Power "quality" is the term most often used for relatively short term power disturbances such as:

- Harmonics - result from distortions to the voltage and/or current sine waves and are commonly caused by industrial processes, certain electronic loads, and wiring connections.

- Surges - are caused by over-voltages resulting from lightning, switching on the utility power system, and other causes.

- Sags - are under-voltages on the power system and commonly caused by power failures, downed lines, utility recloser operations, and storms.

Reliability: The term used for longer disturbances or "interruptions" where the issue is not the quality of the wave form of the power flow, but the lack of power flow. 
SB 1298: Senate Bill 1298, a California statute that was enacted in September 2000, requires the California Air Resources Board ("CARB" or "Board") to adopt uniform emission standards for electrical generation technologies that are exempt from air pollution control or air quality management district (district) permit requirements. The statute also directs CARB to establish a certification program for technologies subject to these standards. SB 1298 mandates two levels of emission standards for affected DG technologies. The law requires that the first set of standards be effective on January 1, 2003, and reflect the best performance achieved in practice by existing electrical generation technologies that are exempt from district permits. The law also requires that, by the earliest practicable date, the standards be made equivalent to the level determined by the $\mathrm{ARB}$ to be the best available control technology (BACT) for permitted central station power plants in California. See http://www.arb.ca.gov/energy/dg/dg.htm.

SCONO ${ }^{\text {TM: }}$ The $\mathrm{SCONO}_{\mathrm{X}}{ }^{\mathrm{TM}}$ system is a relatively new $\mathrm{NO}_{\mathrm{X}}$ control technology that eliminates the use of ammonia as a reagent. $\mathrm{SCONO}_{\mathrm{X}}^{\mathrm{TM}}$ absorbs $\mathrm{NO}_{\mathrm{x}}$ onto a surface that is periodically regenerated with a hydrogen-rich gas. During regeneration, the $\mathrm{NO}_{\mathrm{x}}$ is converted to nitrogen and water. $\mathrm{SCONO}_{\mathrm{X}}{ }^{\mathrm{TM}}$ has been shown to achieve very low- $\mathrm{NO}_{\mathrm{x}}$ levels in a few installations. $\mathrm{SCONO}_{\mathrm{X}}^{\mathrm{TM}}$ does not use ammonia but is mechanically more complicated and even more expensive than SCR.

Selective catalytic reduction (SCR): $\mathrm{SCR}$ is the most common add-on $\mathrm{NO}_{\mathrm{x}}$ control system in use for stationary technologies that cannot use a three-way catalyst due to excess air in their exhaust (lean-burn engines, diesel engines, and combustion turbines). SCR works by injecting ammonia into the exhaust gas in the presence of a catalyst bed. The ammonia reacts with the $\mathrm{NO}_{\mathrm{x}}$ in the exhaust gas to form nitrogen and water. SCR has been shown to be very effective in reducing $\mathrm{NO}_{\mathrm{x}}$ emissions, typically by up to $90 \%$.

State Implementation Plan (SIP): A collection of the regulations a state will use to clean up polluted areas.

T\&D losses: (Transmission and distribution losses). Electricity that is consumed in the process of being delivered from central generators to end users. The Energy Information Agency estimates that approximately $9 \%$ of the energy value of the total fuels used to generate electricity in the United States is lost to waste heat and powering the nation's T\&D systems.

Texas Natural Resource Conservation Commission (TNRCC): Texas state environmental agency. See http://www.tnrcc.state.tx.us/.

Three-way catalyst (TWC): The 3-way catalyst is a pollution control device that gets its name because it reduces emissions of $\mathrm{NO}_{\mathrm{x}}, \mathrm{CO}$, and unburned hydrocarbons. It is the same technology used to control emissions from automobiles. It is a passive technology that is efficient and relatively simple. However, it can only be used when there is no excess oxygen in the exhaust stream. For this reason it cannot be used for lean-burn gas engines, diesel engines, and combustion turbine systems, which operate at fuel/air ratios that result in high excess exhaust oxygen.

TPY: Tons per year. Unit for measuring thresholds for NSR and other permitting requirements. 
Waste heat: The heat, and thus energy, lost in conventional generation processes. EIA estimates total energy value wasted in the U.S. electricity system to be approximately $662 / 3 \%$.

Waste or by-product fuels: Fuels otherwise lost or flared. For example, landfills and many industrial processes produce combustible fuels in quantities that do not justify their collection and transport for other uses. However, DG technologies can be used to generate electricity and heat from those gases otherwise lost or burned unproductively. 
Public reporting burden for this collection of information is estimated to average 1 hour per response, including the time for reviewing instructions, searching existing data

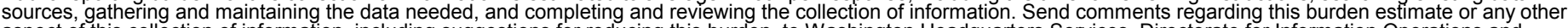
, Washington Headquarters Services, Directorate for Information Operations and Reports, 1215 Jefferson Davis Highway, Suite 1204, Arlington, VA 22202-4302, and to the Office of Management and Budget, Paperwork Reduction Project (0704-0188), Washington, DC 20503.
1. AGENCY USE ONLY (Leave blank)
2. REPORT DATE October 2002
3. REPORT TYPE AND DATES COVERED Subcontract Report, 10 April 2002-10 May 2002

4. TITLE AND SUBTITLE

The Impact of Air Quality Regulations on Distributed Generation

5. FUNDING NUMBERS

6. $\mathrm{AUTHOR}(\mathrm{S})$

J. Bluestein, S. Horgan, and M. M. Eldridge

7. PERFORMING ORGANIZATION NAME(S) AND ADDRESS(ES)

Energy and Environmental Analysis, Inc., Arlington, Virginia

Distributed Utility Associates, Livermore, California

Competitive Utility Strategies, Boulder, Colorado

DP02.1001

9. SPONSORING/MONITORING AGENCY NAME(S) AND ADDRESS(ES)

National Renewable Energy Laboratory

1617 Cole Blvd.

Golden, CO 80401-3393

8. PERFORMING ORGANIZATION REPORT NUMBER

ACM-2-32039-01

10. SPONSORING/MONITORING AGENCY REPORT NUMBER

NREL/SR-560-31772

11. SUPPLEMENTARY NOTES

NREL Technical Monitor: Gary Nakarado

12a. DISTRIBUTION/AVAILABILITY STATEMENT

National Technical Information Service

12b. DISTRIBUTION CODE

U.S. Department of Commerce

5285 Port Royal Road

Springfield, VA 22161

13. ABSTRACT (Maximum 200 words)

Relatively small projects for generating electrical power at or near the point of use —distributed generation (DG) - offer unique opportunities for enhancing the U.S. electric system. This report finds that current air quality regulatory practices are inappropriately inhibiting the development of DG through a failure to recognize the environmental benefits offered by DG or by imposing requirements designed for larger systems that are not appropriate to DG systems. The report recommends that air quality regulation be made more efficient and appropriate for DG by establishing national standards for DG equipment. This report also recommends that DG projects be evaluated on a "net" emissions basis by being given credit for any emission sources that they displace. Air quality regulation should also recognize the benefits of combined heat and power (CHP).

14. SUBJECT TERMS

Distributed Generation; Air Quality Regulation

15. NUMBER OF PAGES

16. PRICE CODE

17. SECURITY CLASSIFICATION OF REPORT

Unclassified
18. SECURITY CLASSIFICATION OF THIS PAGE Unclassified
19. SECURITY CLASSIFICATION OF ABSTRACT Unclassified
20. LIMITATION OF ABSTRACT

UL 


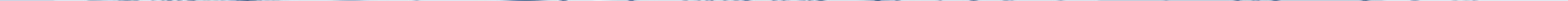

